\title{
Die invloed van rekenarisering op die leksikografiese terminologie 1
}

\author{
Pieter Harteveld, Buro van die Woordeboek van die Afrikaanse Taal (WAT),
} Stellenbosch, Suid-Afrika

\begin{abstract}
The Influence of Computerization on Lexicographical Terminology. Where new technological developments like the computer and new scientific disciplines like computer science penetrate existing fields of study, they influence them terminologically. This is also the case with computerized lexicography.

In this article recent lexicographical terminology is looked at inter alia in the light of publications by F.J. Hausmann and H.E. Wiegand in order to make provision in this terminology for the relatively new field of computer lexicography which, just like the so-called field of manual lexicography, is regarded here as a subfield of lexicography.

In view of their naming, certain lexicographic phenomena are looked into more closely. New terms that refer specifically to computer lexicography, as well as alternatives to certain established terms in lexicographic theory and practice, are consequently proposed. These proposals enable the terminology of computer lexicography and the terminology of the older manual lexicography to join seamlessly. In this way, terminological unity in lexicography is ensured.
\end{abstract}

Keywords: COMPUTERIZATION, LEXICOGRAPHY, MANUAL LEXICOGRAPHY, COMPUTER LEXICOGRAPHY, LEXICOGRAPHICAL TERMINOLOGY, COMPUTER LEXICOGRAPHICAL TERMINOLOGY, TERMINOLOGICAL UNITY, DICTIONARY ENTRY, FRONT MATTER ENTRY, WORD LIST ENTRY, BACK MATTER ENTRY, INFORMATION ENTRY, STRUCTURAL MARKER, ACCESS ENTRY, USER ACCESS ENTRY, COMPUTER ACCESS ENTRY

Opsomming: Waar nuwe tegnologiese ontwikkelinge soos die rekenaar en nuwe wetenskaplike dissiplines soos die rekenaarwetenskap bestaande vakgebiede binnedring, oefen hulle terminologies ' $n$ invloed daarop uit. Dit is die ook geval in die gerekenariseerde leksikografie.

In hierdie artikel word daar onder andere aan die hand van publikasies van F.J. Hausmann en H.E. Wiegand en gekyk na resente leksikografiese terminologie ten einde in hierdie terminologie voorsiening te maak vir die relatief nuwe terrein van die rekenaarleksikografie, wat hier, net soos die terrein van die sogenaamde handleksikografie, as 'n subterrein van die leksikografie beskou word.

Met die oog op hulle naamgewing word enkele leksikografiese verskynsels van naderby beskou. Nuwe terme wat spesifiek op die rekenaarleksikografie betrekking het en alternatiewe vir

Hierdie artikel is 'n verkorte en aangepaste hoofstuk uit 'n M.A.-verhandeling Die invloed van rekenarisering op die leksikografiese praktyk in die Buro zan die WAT, wat in Maart 1994 deur die Universiteit van Stellenbosch aanvaar is. 
sekere gevestigde terme in die leksikografieteorie en -praktyk word vervolgens voorgestel. Hierdie voorstelle maak dit moontlik dat die rekenaarleksikografie terminologies naatloos by die ouer handleksikografie aansluit. Sodoende word die terminologiese eenheid in die teksikografie verseker.

Sleutelwoorde: REKENARISERING, LEKSIKOGRAFIE, HANDLEKSIKOGRAFIE, REKENAARLEKSIKOGRAFIE, LEKSIKOGRAFIESE TERMINOLOGIE, REKENAARLEKSIKOGRAFIESE TERMINOLOGIE, TERMINOLOGIESE EENHEID, WOORDEBOEKINSKRYWING, VOORWERKINSKRYWING, WOORDELYSINSKRYWING, AGTERWERKINSKRYWING, AAN. GAWE, STRUKTUURAANWYSER, TOEGANGSINSKRYWING, GEBRUIKERTOEGANGSINSKRYWING, REKENAARTOEGANGSINSKRYWING

\section{Inhoud}

1. INLEIDING

2. INSKRYWINGS, INLIGTING EN INLIGTINGSTIPES

$2.1 \quad$ Woordeboekinskrywings en woordeboekinligting

2.2 Woordelysinskrywings

2.3 Artikelinskrywings

2.4 Woordeboekinskrywingstipes en woordeboekinligtingstipes

3. AANGAWES

4. STRUKTUURAANWYSERS

4.1 Tipografiese struktuuraanwysers

4.2 Nietipografiese struktuuraanwysers

5. TOEGANGSTRUKTUUR

6. TOEGANGSINSKRYWINGS

6.1 Gebruikertoegangsinskrywings

6.1.1 Leksikale gebruikertoegangsinskrywings

6.1.2 Nieleksikale gebruikertoegangsinskrywings

6.1.3 Tipografiese gebruikertoegangsinskrywings

6.1.4 Nietipografiese gebruikertoegangsinskrywings

6.2 Rekenaartoegangsinskrywings

6.2.1 Rekenaarmerkers

6.2.2 Redaksionele kommentaar

7. SAMEVATTING

VERWYSINGS

BYLAES: SKEMAS 1-6

\section{INLEIDING}

Nuwe tegnologiese ontwikkelinge soos die rekenaar en nuwe wetenskaplike terreine soos die rekenaarwetenskap verg elk sy eiesoortige terminologie. 
Waar sulke nuwe ontwikkelinge en wetenskappe bestaande vakgebiede sterk beïnvloed, moet verwag word dat hierdie terminologie nie alleen daardie vakgebiede sal binnedring nie maar ook daartoe kan lei dat 'n betrokke vakgebied se bestaande terminologie by die ontwikkeling aangepas sal moet word. Dit geld ook die leksikografie. Die rekenaar as hulpmiddel oefen reeds só ' $n$ ingrypende invloed daarop uit dat rekenaarterme part en deel van die gerekenariseerde leksikografie geword het.

Daar bestaan trouens selfs ' $n$ behoefte om te onderskei tussen hierdie leksikografie met behulp van die rekenaar, wat reeds algemeen as rekenaarleksikografie bestempel word, en die leksikografie soos dit tradisioneel met die hand beoefen is. Ook moet sekere gevestigde terme in die leksikografieteorie en -praktyk deur ander terme vervang of die betekenis daarvan aangepas word om vir die rekenaarleksikografie voorsiening te maak. Op hierdie veranderinge sal daar in dié artikel ingegaan word.

Dit is ten aanvang nodig om 'n onderskeidende term vir die genoemde tradisioneel beoefende leksikografie vas te stel. Hierdie behoefte is ook al deur ander aangevoel. 'n Mens kry egter die indruk dat ander gewoonlik van omskrywings gebruik gemaak het om die begrippe te onderskei. Van Sterkenburg (1984: 174) stel byvoorbeeld nie eksplisiet 'n term voor nie maar noem "meganies" (wat hier op die rekenaar slaan) teenoor "tradisioneel". Na aanleiding daarvan sou 'n mens "tradisionele leksikografie" as teenhanger vir rekenaarleksikografie kon oorweeg. Aangesien dié term egter nie te kenne gee in watter opsig die leksikografie tradisioneel is nie, lyk handleksikografie na 'n beter onderskeidende en korter term daarvoor. Ook in Engels bestaan daar klaarblyklik 'n behoefte aan so 'n term: Weiner (1990: 23) noem dit nog informeel "the horse-and-buggy method [...] with pen, paper, and dictionary slips". Die volgende vertaalekwivalente word dus voorgestel: Engels manual lexicography; Duits Handlexikographie, manuelle Lexikographie. Waar die oorweging van teenstelling met rekenaarleksikografie nie geld nie, sal daar in plaas van na handleksikografie steeds bloot na leksikografie verwys word.

In die verdere terminologiese uiteensetting word daar grootliks geleun op die baanbrekende werk van H.E. Wiegand en F.J. Hausmann soos saamgevat in Wiegand (1989, 1989a, 1989b, 1989c) en in Hausmann en Wiegand (1989). Om hierdie rede word hier, waar nodig geag, benewens die Afrikaanse term ook dié outeurs se Engelse en Duitse ekwivalente gegee. Dit maak dit moontlik om meer besonderhede oor die terminologie in te win. Voorstelle vir nuwe terme gaan in hierdie artikel ook sover moontlik gepaard met Engelse en Duitse vertaalekwivalente.

Wiegand en Hausmann benader die woordeboek as 'n eiesoortige teks en is gevolglik sterk teksterminologies georiënteerd in hulle voorstelle vir 'n standaard- leksikografiese vakterminologie. Vergelyk hier veral Hausmann en Wiegand (1989) en Wiegand (1989a, 1989b). In hierdie artikel word daar soms van hulle terminologie afgewyk waar dit bots met die reeds in Afrikaans gevestigde terminologie soos dit veral in die Buro van die WAT gangbaar is. Ook 
word die meeste illustrasiemateriaal vir hierdie terminologie uit die WAT geneem.

Omdat gerekenariseerde leksikografiese prosesse, soos reeds aangedui, om ' $n$ eie bykomende terminologie vra, sal daar vanselfsprekend soms ook van die terminologie van Hausmann en Wiegand (1989) en van Gouws (1989) afgewyk word waar dit ter wille van 'n goeie aansluiting tussen die hand- en rekenaarleksikografiese terminologie nodig blyk te wees.

\section{INSKRYWINGS, INLIGTING EN INLIGTINGSTIPES}

Vervolgens word die belangrikste soorte inskrywings in 'n woordeboek en die inligting wat hulle aan die gebruiker kan verskaf, uiteengesit ten einde enkele voorstelle vir toepasliker en bykomende terme teen die geldende terminologiese agtergrond te plaas.

\subsection{Woordeboekinskrywings en woordeboekinligting}

Dit is hier nodig om tussen die terme woordeboekinskrywing en woordeboekinligting te onderskei in samehang met enkele aanverwante terme. Gouws (1989: 37) gee die volgende definisie van eersgenoemde: "Die term woordeboekinskrywing verwys na 'n onderafdeling van die woordeboekartikel." Uit die verband kan afgelei word dat hy "woordeboek-" in die samestelling "woordeboekinskrywing" beskou as slegs betrekking hebbend op die sentrale woordelys in 'n woordeboek en nie op die hele woordeboek met sy vooren agterwerk nie. (Sien Hausmann en Wiegand 1989: 328, 331 vir dié meerduidigheid van "woordeboek" asook vir 'n uiteensetting van die onderskeid tussen die voorwerk, woordelys en agterwerk van 'n woordeboek en tussen hulle verskillende onderafdelings. Oor laasgenoemde drie terme word hier onder meer gesê.)

Vir die doeleindes van hierdie artikel blyk Gouws se verklaring van woordeboekinskrywing te beperkend te wees aangesien dit daardie funksionele komponente van ' $n$ woordeboek uitsluit wat uiteraard deel van die totale woordeboekinhoud maar nie deel van die woordeboekartikel vorm nie. Voorbeelde van sulke komponente is die toeligting binne die voorwerk van die woordeboek, die indeksletters in die vorm van gewoonlik groot gedrukte hoofletters, wat die ooreenstemmende alfabetiese seksies binne die woordelys van die woordeboek aandui en hulle in die vorm van opskrifte voorafgaan, die sleutelwoorde boaan elke bladsy van hierdie woordelys en verder die bibliografiese besonderhede binne die agterwerk van die woordeboek.

Gouws se definisie van woordeboekinskrywing stem inhoudelik grootliks ooreen met wat Wiegand (1989b: 425) Textsegment noem. Omdat albei outeurs se definisies sterk artikelgerig is, sal dit wat Gouws hier bo as woorde- 
boekinskrywing en Wiegand as Textsegment aandui, in hierdie bespreking artikelinskrywing genoem word (voorgestelde vertaalekwivalente: Engels article entry of article item; Duits Artikeleintrag, as alternatief vir Textsegment). Die term woordeboekinskrywing (voorgestelde vertaalekwivalente: Engels dictionary entry of dictionary item; Duits Wörterbucheintrag) sal hier verwys na enige funksionele komponent of funksionele element (Engels component part of element; Duits Bauteil) van 'n woordeboek in sy totaliteit (Hausmann en Wiegand 1989: 330; Wiegand 1989b: 425). (Let wel: Duits Bauteil moet nie verwar word met Textbaustein nie. Vir laasgenoemde sien Wiegand 1989b: 426.)

Onder die funksionele komponente waarna die term woordeboekinskrywing in hierdie artikel verwys, word alles gereken wat volgens die teksbeskoulike siening van Hausmann en Wiegand (1989: 330 e.v.) tot óf die tekstuele óf die nietekstuele inhoud van die woordeboek behoort. Die tekstuele inhoud van die woordeboek sluit daarvolgens al die selfstandige teks van die voorwerk, die woordelys(te) en die agterwerk van die woordeboek in. ("Tekstueel" moet hier nie met "leksikaal" verwar word nie.) Die nietekstuele inhoud omvat volgens hulle alles in die woordeboek wat nie 'n selfstandige teks vorm nie. As nietekstuele inhoud reken Hausmann en Wiegand (1989: 330, 335) spesifiek die indeksletters en die sleutelwoorde. Ook 'n tekssegment is nie vir hulle deel van die tekstuele inhoud nie. Dit word duidelik as in gedagte gehou word dat 'n tekssegment selfs niks meer as die vet of kursiewe formatering van teks hoef te wees nie.

Saam maak die woordeboekinskrywings die woordeboekstruktuur (Engels book structure of dictionary structure; Duits Wörterbuchstruktur) uit. Hierdie woordeboekstruktuur kan deur segmentering vasgestel word. Segmentering is ' $n$ wetenskaplike ontledingsmetode waarsonder 'n betroubare en eenvormige metaleksikografiese woordeboekbeskrywing nie moontlik is nie (Wiegand 1989b: 437-440). Dit kan gebruik word om die hele woordeboekstruktuur of sy deelstrukture, byvoorbeeld die woordelys-, makro- en mikrostruktuur, te analiseer. Dit geld die tekstuele sowel as die nietekstuele inhoud. Hausmann en Wiegand (1989: 330 e.v.) en Wiegand (1989b: 423 e.v.) gee duidelike uiteensettings en grafiese voorstellings van die mees tipiese woordeboekstrukture soos tot op mikrostruktuurvlak deur segmentering bepaal.

Die woordeboek bestaan gewoonlik uit die voorwerk (Engels front matter; Duits Vorspann), woordelys (Engels word list; Duits Wörterverzeichnis) en agterwerk (Engels back matter; Duits Nachspann). Die voorwerk is op sy beurt gewoonlik saamgestel uit die titel, impressum, inhoudsopgawe, gebruikstoeligting en redaksionele afkortings; die woordelys bestaan uit die woordeboekartikels en meestal daartussen die indeksletters en boaan elke bladsy een of meer sleutelwoorde; die agterwerk word gewoonlik gevorm deur die bronnelys en die verbeteringe in die woordelys. Binne die woordelys kan daar soms ook een of meer komponente ingevoeg word wat nie deel van hierdie woordelys uitmaak nie. So ' $n$ invoegsel (Engels insert; Duits Einschub) vorm dan deel van die middelwerk (Engels middle matter; Duits Zwischenspann). Omdat middel- 
werkinskrywings grootliks van dieselfde aard as agterwerkinskrywings is, word hulle nie verder bespreek nie.

Inskrywings in elk van hierdie geledinge kan met 'n eie term benoem word. Soos reeds aangedui, sal alles wat in die vorm van 'n funksionele komponent (funksionele element) in die woordeboek in sy geheel aangebied word, in hierdie artikel woordeboekinskrywings heet. 'n Woordeboekinskrywing wat spesifiek tot die voorwerk of die agterwerk behoort, word onderskeidelik 'n voorwerkinskrywing (Engels front matter entry; Duits Vorspanneintrag) en 'n agterwerkinskrywing (Engels back matter entry; Duits Nachspanneintrag) genoem. Enige funksionele komponent wat net in die woordelys aangetref word, kan as 'n woordelysinskrywing (Engels word list entry; Duits Wörterverzeichniseintrag) bekend staan. In die woordelys word die funksionele komponente binne die artikel artikelinskrywings genoem. Die segmentering van die hiërargiese woordeboekstruktuur, en daarmee ook die naamgewing vir die geidentifiseerde inskrywings, kan deurgevoer word tot daardie kleinste ondeelbare funksionele komponente wat Wiegand (1989b: 426) die tekselemente noem.

So hiërargies gesien, is elkeen van hierdie inskrywings ook 'n woordeboekinskrywing, maar nie andersom nie. 'n Mens het hier dus met 'n hiponimiese verhouding te doen.

Volgens Hausmann en Wiegand (1989: 331) is die meeste van die komponente in die voor- en agterwerk opsioneel; trouens, net die woordelys en die toeligting tot hierdie woordelys, wat deel van die voorwerk uitmaak, is verpligte komponente van die woordeboek. Die woordelys- en voorwerkinskrywings vorm dus in dié orde die kern van enige woordeboek en moet gevolglik ook die nougesetste aandag van die leksikograaf en die metaleksikograaf geniet. In hierdie artikel word hoofsaaklik aan die artikelinskrywings aandag gegee aangesien die rekenaarleksikografie veral hier om terminologiese aanpassing en aanvulling vra.

Woordeboekinligting (Engels dictionary information; Duits Wörterbuchinformation), ter onderskeiding van woordeboekinskrywing is die funksionele inligting wat deur een of meer woordeboekinskrywings verstrek word.

Met "funksioneel" word hier bo en vervolgens telkens, in aansluiting by Wiegand (1989b: 425), aangedui dat iets ten minste een "ware doel" (dit wil sê 'n primêre funksie) het. Wiegand het dit hier oor artikelinskrywings (wat hy "Textsegmente" noem), maar dit is op alle woordeboekinskrywings van toepassing. Die primêre funksie moet nie met enige ander funksie verwar word nie. Wiegand (1989b: 426) wys byvoorbeeld daarop dat 'n betekenisparafrase ook sintaktiese inligting kan verstrek, maar die primêre funksie bly enkel dat dit betekenisverklarend is.

'n Woordeboekinskrywing kan ook niefunksioneel wees, byvoorbeeld in die sin dat dit geen onderskeibare ware doel het nie. Dit is veral op artikelvlak 'n groot en aktuele leksikografiese probleem. Wiegand (1988: 770) identifiseer en demonstreer hierdie verskynsel soos dit hom nog in die moderne leksiko- 
grafie voordoen. Ooreenkomstig sy opvatting van betekenis verklaar hy sulke inskrywings dan oorbodig ("redundant"). Betreffende die bykans onoorkomelikheid van die probleem om hierdie soort niefunksionele inskrywings van funksionele inskrywings te onderskei, word na Wiegand (1989d: 550 e.v.) verwys. 'n Enkele voorbeeld kan hier ter illustrasie dien.

In die definisie van kom $^{2}$ I in WAT deel VII staan daar onder meer:

I/d alg, selfstandig beweeg of, passief, gebring word (lett. of fig. in talryke bepalende verbande) na 'n eind-, doel- of waamemingspunt [...].

Dit handel hier om die gedeelte tussen ronde hakies. 'n Mens sou jou reeds kon afvra of dit nodig is om aan te dui dat 'n lemma letterlik of figururlik gebruik kan word; as die lemma ten opsigte van hierdie aanwendings ongemerk is, sou dié vermelding sonder nadelige gevolge weggelaat kon word. Daarom kan dit as redundant bestempel word. Tog is daar leksikograwe wat anders hieroor voel. Die redenasie verloop ongeveer soos volg daaroor: Daar is só baie óf-óf-moontlikhede of -gebruiksvoorwaardes in die taal dat dit beslis leiding aan die gebruiker gee indien die markantstes onder hulle, byvoorbeeld onverwagse alternatiewe optredes, uit die leksikografiese bewerking van die lemma sou blyk en hulle eksplisiet meegedeel word. 'n Tipiese voorbeeld is "van mense en diere" waar dit klaarblyklik net om lewende wesens kán handel, byvoorbeeld in WAT deel VII:

kop'geskud. 1. Hoofgeskud (bet. 1) - van mense en diere: [...].

Wanneer die verwysing na hoofgeskud (bet. 1) opgevolg word, is daar in 'n sekere mate begrip vir die hanteringswyse van kopgeskud. Op die moontlike motivering daarvoor hoef hier nie ingegaan te word nie. Wel blyk daaruit waarom hier bo gepraat is van "die bykans onoorkomelikheid van die probleem om hierdie soort niefunksionele inskrywings van funksionele inskrywings te onderskei".

Tog is daar gevalle waaroor daar nie twyfel hoef te wees nie. So 'n voorbeeld vind ' $n$ mens verder in dieselfde aanhaling "(lett. of fig. in talryke bepalende verbande)". Die gedeelte "in talryke bepalende verbande" dra geen funksionele inligting tot die begrip van die inskrywing of van die lemma by nie, want alle taalgebruik word deur verbande bepaal. Die bepaling "talryke" verteenwoordig 'n bykomende redundansie.

Die konsekwente toepassing van 'n goed ontwikkelde rekenaarveldstruktuur vir die aanbied van die verskillende artikelinskrywings in die woordeboek kan 'n belangrike bydrae lewer om oorbodige artikelinskrywings daaruit te weer. Dit kom daarop neer dat die redakteur deur die veldstruktuur gewaarsku sal word indien hy 'n inskrywing wil maak waarvoor daar nie 'n veld in die struktuur bestaan nie. Alhoewel dit teen growwe foute waak, sal dit nie oorbodige inskrywings binne 'n aangawe kan voorkom nie - korrekt- 
heid berus hier volkome op die oordeel van die redakteur.

'n Woordeboekinskrywing kan veral op die vlak van die voor- of agterwerk ook niefunksioneel en oorbodig wees deurdat sy funksie glad nie vir die woordelys van die betrokke woordeboek ter sake is nie. Aan die einde van afdeling 6.1.2 hier onder word 'n voorbeeld uitgewys van 'n niefunksionele voorwerkinskrywing in die WAT, naamlik in die vorm van kleurplate van vlae uit die Suid-Afrikaanse geskiedenis. Aangesien sulke inskrywings nie in 'n nieensiklopediese woordeboek tuishoort nie en hierdie artikel ook nie in die eerste plek oor voorwerkinskrywings handel nie, sal daar nie indringende aandag hieraan gegee word nie.

Wiegand (1989b: 425) wys daarop en illustreer dat 'n mens by die analise van byvoorbeeld 'n woordeboekartikel ook 'n niefunksionele inskrywing sou kon isoleer wat nie noodwendig die resultaat van verkeerde redaksionele bewerking is nie maar wel van verkeerde segmentering deur die gebruiker. Die verkeerde segmentering openbaar hom daarin dat die vermeende funksionele inskrywing geen onderskeibare enkele ware doel blyk te hê nie. Dit vra dan om 'n nuwe segmentering ten einde te bepaal of die inskrywing inderdaad oorbodig is. Ook hierdie soort probleem sal nie verder hier bespreek word nie.

\subsection{Woordelysinskrywings}

'n Woordeboekinskrywing wat spesifiek deel van die woordelys in 'n woordeboek uitmaak, is hier bo 'n woordelysinskrywing (Engels word-list entry; Duits Wörterverzeichniseintrag) genoem. So 'n woordelysinskrywing kan tekstueel of nietekstueel wees. Saam maak die woordelysinskrywings die woordelysstruktuur (Engels word list structure; Duits Wörterverzeichnisstruktur) uit (sien ook Hausmann en Wiegand 1989: 333 e.v.). Net soos in die woordeboekstruktuur vind 'n mens hier ook 'n hiërargiese geleding wat deur segmentering vasgestel kan word.

Die woordelys bestaan uit die artikels (gewoonlik in alfabetiese orde volgens die lemma gegroepeer) met daartussen die indeksletters. Die artikels is tekstuele inskrywings en behoort tot die tekstuele woordelysstruktuur. In die woordelys het elke artikel 'n mikrostruktuur (Engels microstructure; Duits Mikrostruktur). Dit is die geordende versameling van al die inskrywings binne 'n woordeboekartikel maar met uitsluiting van die lemma self. (Vergelyk hier Hausmann en Wiegand (1989: 328), Wiegand (1989b: 422) en Gouws (1989: 40)). Die makrostruktuur (Engels macrostructure; Duits Makrostruktur) is die geordende versameling van al die lemmas in die woordeboek. (Vergelyk Hausmann en Wiegand (1989: 328) en Gouws (1989: 40)). Indien daar twee of meer woordelyste in die woordeboek voorkom, is daar twee of meer woordelysstrukture maar slegs een gemeenskaplike makrostruktuur. Alleen indien daar net een woordelys in die woordeboek voorkom, is die makrostruktuur identies aan die woordelysstruktuur. 
Die duimindeks, indeksletters en die sleutelwoorde is volgens Hausmann en Wiegand (1989: 330 e.v.) funksionele woordelysinskrywings maar nie selfstandige tekste nie. Hoewel hulle funksies met mekaar vergelykbaar is wat die verlening van toegang tot die inligting in die artikel betref, word hulle nie deur 'n gemeenskaplike metaleksikografiese term aangedui nie. Hulle kan wel in terme van die woordelys waarbinne hulle voorkom, omskryf word as (artikel)eksterne woordelysinskrywings. In afdeling 6 hier onder word daar ' $n$ ander oorkoepelende term vir hulle voorgestel.

Die belangrikste woordelysinskrywing is die artikel. Dit is ' $n$ eenheid in 'n woordeboek wat deur die (van sy homoniem voorsiene) lemma, die leksikale item waaroor die gebruiker inligting in die woordeboek soek, ingelui en net voor die (veronderstelde) volgende bewerkte lemma afgesluit word. (Vir die laaste artikel in die woordelys geld die definisie met insluiting van die teks tussen hakies. Só 'n artikel se einde val dus saam met die einde van die hele woordelys of, anders uitgedruk, die laaste artikel in die woordelys word getermineer net voor 'n veronderstelde volgende bewerkte lemma. Vir woordeboeke met vooropgeplaaste homoniemnommers, soos die WAT vanaf deel IX, moet so 'n nommer voor die lemma ingereken word.)

Die vermelding van "voor" en "bewerkte lemma" in die definisie van artikel is belangrik: In die WAT staan die onverklaarde samestellings en afleidings byvoorbeeld binne die artikel, en dit terwyl hulle én op die een of ander wyse bewerk is (vergelyk die klem- en woordsoortaanduiding in deel IX) én as lemmas kwalifiseer (sien onder andere Gouws 1989: 36, 77). Die artikel strek hier dus nie van die een bewerkte lemma tot die volgende bewerkte - maar onverklaarde - lemma nie. So 'n definisie sou van 'n woordelys bestaande uit onverklaarde - maar wel bewerkte - lemmas kon geld. In die WAT strek die artikel dus van die een verklaarde lemma tot net voor die volgende verklaarde lemma, oftewel soos dit hier bo gedefinieer is.

In die artikel word alle tersaaklike inligting oor die betrokke leksikale item verstrek. Vergelyk hier Gouws (1989: 36, 38). Die artikel het weer sy eie struktuur en kan verder deur segmentering tot by die kleinste element geanaliseer en benoem word.

Sien Skema 1 onder Bylaes vir 'n kort uiteensetting van die belangrikste woordeboekinskrywings.

\subsection{Artikelinskrywings}

Onder die term artikelinskrywing (voorgestelde vertaling: Engels article entry of article item; Duits Artikeleintrag, as alternatief vir Textsegment) word, in aansluiting by Wiegand (1989b: 426 e.v.) se siening van die "Textsegment", enige "funksionele komponent" van die artikel gereken, naamlik alles wat Gouws (1989: 38) as 'n "woord, sin, syfer, lees- of diakritiese teken asook ander tipografiese hulpmiddele" identifiseer.

Elke artikelinskrywing is, soos reeds vermeld, altyd 'n soort woordeboek- 
inskrywing, maar die omgekeerde geld nie. Waar daar voortaan van inskrywing sprake is, kan dit dus op enigeen slaan. Die bedoeling sal gewoonlik uit die verband blyk. Wanneer daar twyfel kan ontstaan, word die spesifieke vol vorm van die term hier gebruik.

Die hier bo aangeduide betekenisverruiming van woordeboekinskrywing en die invoer van die subkategorieë, onder andere die term artikelinskrywing, is die regstreekse gevolg van die behoefte aan 'n terminologie wat ook die rekenaarleksikografie bedien. As voorbeeld kan genoem word dat die term woordeboekinskrywing nou ook voorsiening maak vir inskrywings soos die rekenaarveldstruktuur wat in verskuilde teks binne die teks van die WAT opgesluit lê (sien afdeling 6.2.1 oor Rekenaarmerkers hier onder). Alhoewel die gebruiker dit waarskynlik nooit te siene kry nie, moontlik nie eets in 'n elektroniese woordeboek nie, is dit tog deel van die gerekenariseerde WAT en moet dit terminologies geïdentifiseer word. Vir sover Wiegand (1989a: 372) spesifiek van die term makrostruktuur sê dat dit van toepassing is op alle "maschinenexternen und nichtelektronischen [...] Wörterbücher", gee hy te kenne dat daar terme in die leksikografie is wat dalk nie op elektroniese woordeboeke van toepassing is nie. Daarmee laat hy wyslik in beginsel ruimte vir 'n bykomende terminologie wat wel vir die rekenaarleksikografie voorsiening sal maak.

\subsection{Woordeboekinskrywingstipes en woordeboekinligtingstipes}

Vervolgens moet woordeboekinskrywingstipe van woordeboekinskrywing en woordeboekinligtingstipe van woordeboekinligting onderskei word:

'n Woordeboekinskrywingstipe is enige klas of soort inskrywing in 'n woordeboek. Een of meer woordeboekinskrywings van 'n bepaalde soort verteenwoordig 'n woordeboekinskrywingstipe. Dienooreenkomstig is 'n woordeboekinligtingstipe enige klas of soort inligting in 'n woordeboek. Voorbeelde van woordeboekinligtingstipes en tewens van woordeboekinskrywingstipes is die toeligting tot die woordeboek en die sleutel vir die fonetiese transkripsie en afkortings in die voorwerk; die woordsoortaanduiding, definisie, sinonieme, homonieme, uitdrukkings en voorbeelde in die sentrale woordelys (Hausmann en Wiegand 1989: 341); die bronnelysinskrywings in die agterwerk. In hierdie artikel sal daar in die reël voorkeur aan die term woordeboekinligtingstipe bo woordeboekInskrywingstipe gegee word, tensy dwingende redes vir die teendeel geld. Die volgende twee woordeboekinskrywings (meer bepaald artikelinskrywings), naamlik sitate in WAT deel IX, verteenwoordig een woordeboekinligtingstipe (tewens woordeboekinskrywingstipe) omdat hulle soortgelyk is:

Ek het my ... misgis met die breedte van die rivier met die gevolg dat my skote, hoewel raak, almal te leeg was (J. v. Moltke: Veldsmanne, 1958, 114). Die water is aan die sak en amper op sy leegste (Sarie, 30 Aug. 1967, 33).

[Onder ${ }^{2}$ leeg I.] 
Binne die leksikografiese konteks en binne die konteks van hierdie artikel word die terme woordeboekinligting en woordeboekinskrywing dikwels verkort tot onderskeidelik inligting en inskrywing, terwyl woordeboekinligtingstipe en woordeboekinskrywingstipe gewoonlik verkort word tot onderskeidelik inligtingstipe en inskrywingstipe. Die moontlikheid van verkorting geld ook die meeste van die ander terme wat bespreek word, soos reeds onder afdeling 2.3 hier bo ten opsigte van die terme artikelinskrywing en woordeboekinskrywing aangedui is. Dié feit word gevolglik nie elke keer vermeld nie.

Die terminologie hier bo kan nou nader geillustreer word aan die hand van die volgende vetgedrukte gedeelte uit 'n artikel van NW: pre'sies (-, -e; -er, -ste). Dié gedeelte bevat veertien artikelinskrywings (met insluiting van die nieleksikale inskrywings, naamlik die hakies, lees- en skryftekens). In isolasie gesien, lyk dié inskrywings waarskynlik nie sinvol nie, maar binne konteks, en veral vir die kundige woordeboekgebruiker, verstrek hulle gewoonlik wel sinvolle inligting. Enkele van hierdie inskrywings, byvoorbeeld die tweeledige "-ste", is só gekonvensionaliseerd dat hulle onmiddellike inligting oor die eerste inskrywing, naamlik die lemma, verstrek. Sommige inskrywings is minder eenduidig gekonvensionaliseerd, byvoorbeeld die aksentteken wat die woordklem by die lemma aandui en wat in die een woordeboek vóór en in die ander ná die beklemtoonde lettergreep geplaas word.

Verskillende van die inskrywings hier bo kan ooreenkomstig die gekonvensionaliseerde inligting wat hulle verstrek, in drie redelik eenduidig gestandaardiseerde woordeboekinligtingstipes gegroepeer word, naamlik die LEMMA, die UITSPRAAK (hier beperk tot aksentaanduiding en aangegee in die tweeledige inskrywing pre'sies) en die MORFOLOGIE (al die inskrywings binne die hakies), wat bestaan uit die inskrywings met inligting oor die attributiewe vorm (die inskrywings binne die hakies tot net voor die kommapunt) en die inskrywings met inligting oor die trappe van vergelyking (die inskrywings binne die hakies net ná die kommapunt). (Die benaminge van die inligtingstipes is dié wat die Buro van die WAT vir sy rekenaarveldstruktuur gekies het.)

Nie alle soorte woordeboekinligtingstipes, en meer bepaald nie alle soorte wat in die WAT voorkom, sal in hierdie artikel bespreek word nie maar hoofsaaklik dié wat deel uitmaak van of regstreeks slaan op die sentrale woordelys. Onder hulle sal die mikrostrukturele inligtingstipes die meeste aandag geniet.

Uit die $N W$-voorbeeld hier bo blyk al dadelik dat dit in die leksikografie nodig is om die verskillende woordeboekinskrywings (en woordeboekinligtingstipes) onderling nader te onderskei ooreenkomstig hulle aard en funksie. Dit geld nog meer op die redelik nuwe terrein van die rekenaarleksikografie.

\section{AANGAWES}

Die belangrikste soort inskrywing in die woordeboek is die aangawe (Engels information entry / information item; Duits Angabe). Aangawes is die funksionele inskrywings wat in ' $n$ woordeboekartikel aangebied word en waarna die 
gebruiker volgens die betrokke woordeboek se konvensie sal soek om die bedoelde inligting wat daarin vervat is, te ontsluit (Wiegand 1989b: 427). Hierdie inskrywings kan sowel na items binne die artikel as na items buite die artikel heenwys. Aangawes kan ook gerig wees op slegs die lemma (leksikale item) wat in die woordeboek verklaar word of op daardie lemma en die vorm van die woordeboek. Anders gestel: die inskrywings kan inhoudsgerig of inhouds- én struktuurgerig (oftewel vormgerig) wees. Die inskrywings wat ook struktuurgerig is, help die gebruiker om die inligting in die aangawe te ontsluit.

Gouws maak ook af en toe - byvoorbeeld 1989: 37 - melding van "aangawes" maar verleen daar blykbaar nie termstatus aan die woord nie.

Vir die rekenaarleksikografie soos in die Buro van die WAT beoefen, moet daar dadelik 'n aanpassing aan hierdie definisie gemaak word in die sin dat nie alle aangawes noodwendig in die konvensionele oftewel gedrukte weergawe van die woordeboek vir die gebruiker toeganklik sal wees nie. Masereeuw en Serail (1992: 259) waarsku dat daar by die samestelling van 'n elektroniese woordeboek gelet moet word op "a clear distinction between the content of the dictionary and its printed output". Die Engelse vertaalekwivalent wat tans in die rekenaarveldstruktuur van die WAT opgeneem word, verskyn byvoorbeeld nie in die gedrukte weergawe van die woordeboek nie aangesien die WAT 'n eentalige woordeboek is. In 'n elektroniese weergawe sou dit miskien wel opgeneem word. Verder is dié aangawes in die elektroniese WAT-teks van groot waarde vir die toekomstige samestelling van satellietprodukte, dit wil sê van produkte soos kleiner woordeboeke wat van die WAT afgelei is. Hierdie aangawes moet onderskei word van dié waarvan die ware doel is om die rekenaar te help in sy datasoektogte (vergelyk die term rekenaartoegangsinskrywing daarvoor in afdeling 6 hier onder). Ter onderskeiding van laasgenoemde word hier voorgestel dat inskrywings soos die gemelde Engelse vertaalekwivalent gereserveerde aangawes (Engels reserved entries; Duits reservierte Angaben) genoem word: hulle ware doel is dat hulle te eniger tyd in die toekoms in ' $n$ gedrukte of elektroniese woordeboek gepubliseer kan word.

'n Aangawe moet verder gesien word as 'n artikelinskrywing wat die resultaat is van 'n leksikografiese formuleringsproses. Dit bring mee dat die lemma en selfs die hele artikel ook as aangawes beskou kan word omdat die vormlike weergawe daarvan ook die resultaat van so 'n formuleringsproses is (Wiegand 1989b: 427-429). Wiegand (1989b: 428) wys pertinent daarop dat die term aangawe se bestek ("Extension"), waar daar behoefte voor bestaan, uitgebrei kan word om juis die lemma self of die hele artikel of 'n verwysing alternatiewelik kruisverwysing in te sluit. Die artikel maak dan die grootste aangawe in die woordeboek uit.

Aangawes word op die makrostrukturele en mikrostrukturele vlak van die woordelys aangetref. Wiegand (1989c: 468) onderskei 'n stuk of neëntig soorte gestandaardiseerde leksikografiese aangawes. Volgens Hausmann en Wiegand (1989: 341 e.v.) is die lemma die belangrikste aangawe op die makro- 
strukturele vlak. Wat die mikrostrukturele vlak betref, stel Hausmann en Wiegand (1989: 342) dit dat die volgende inligtingstipes die belangrikste binne die raamwerk van die "klassieke opvatting" in die leksikografie is (die mees tipiese aangawes word by elke inligtingstipe tussen hakies verstrek): die verklarende inligting (die definisie), die sintagmatiese inligting (die gebruiksvoorbeelde) en die paradigmatiese inligting (die sinoniem en antoniem). Dit blyk egter dat die volgende mikrostrukturele inligtingstipes soos deur Hausmann en Wiegand (1989: 341) onderskei, al hoe meer en noukeuriger aandag in modeme omvattende en gespesialiseerde eentalige woordeboeke begin geniet: sinchronies onderskeidende inligting (spelling, uitspraak, woordsoortelikheid en verbuiging), diachronies onderskeidende inligting (etimologie) en diasistematiese etiketteringsinligting (temporele, regionale, stilistiese, spesialiteits-, frekwensie- en normatiewe merkers).

'n Aangawe kan na iets binne of buite die artikel heenwys (Wiegand 1989b: 427). So wys byvoorbeeld die definisie heen na die lemma binne dieselfde artikel, die sinoniemverwysing na 'n definisie in 'n ander artikel in dieselfde woordeboek en die sinoniemvermelding weer na 'n ander leksikale item wat in dieselfde woordeboek as lemma opgeneem behoort te wees.

Wiegand (1989b: 429 e.v.) onderskei tussen 'n aantal klasse waarin aangawes ondergebring kan word, naamlik talige (leksikale) en nietalige (nieleksikale), linguistiese en ensiklopediese, implisiete en eksplisiete, gestandaardiseerde en niegestandaardiseerde aangawes. Die verskille wat vir hierdie artikel die swaarste weeg, is dié wat terminologiese implikasies het. Omdat aangawes so uiteenlopend van aard kan wees, naamlik van woordteks (byvoorbeeld die teks van die definisie) tot tekens en simbole (byvoorbeeld alfanumeriese tekens soos " 1 a" wat betekenisonderskeidings aandui, simbole wat in sekere woordeboeke as gebruiksetikette diens doen, aksenttekens, sillabeskeidingstekens en wiskundige simbole) tot formules (byvoorbeeld " $\mathrm{H}_{2} \mathrm{O}$ " vir "water"), sal terme soos "tekstuele inskrywing" en "leksikale inskrywing" nie vir hierdie begrip deug nie. Ook "inhoudelike inskrywing" is nie 'n goeie alternatief vir "aangawe" nie aangesien alle inskrywings, ook dié wat nie aangawes is nie, inhoudelik van aard behoort te wees.

Wiegand (1989c: 468) gee verder 'n oorsig in gealfabetiseerde orde van die neëntig soorte leksikografiese aangawes wat hy as gestandaardiseerd beskou. Hy bepleit nie alleen die verdere standaardisering van hierdie aangawes nie maar ook van die volgorde waarin hulle in eentalige woordeboeke aangebied word (1989: 424). Dit kan volgens hom tot groter teksverdigting ('n kriptieser aanbod) lei sonder dat die gebruiker probleme met die ontsluiting daarvan ondervind. Hy sê verder: "Standardisierung [...] ermöglicht, wenn sie mit Textverdichtung verbunden ist, eine Einsparung von Druckraum" (1989: 425).

Dit is inderdaad so dat woordeboekteks weens die gekonvensionaliseerdheid en selfs gestandaardiseerdheid daarvan 'n groter teksdigtheid as ander geskrewe bronne toelaat. Tog moet daar in die algemeen teen 'n te hoë teksdigtheid gewaak word. Teksverdigting mag nooit die deursigtigheid van die 
inhoud en gevolglik die ontsluitbaarheid van die woordeboek in die gedrang bring nie. Daar moet ook met die geleentheidsgebruiker wat nog nie die betrokke woordeboek se toegangskonvensie ken nie, rekening gehou word.

Die gevaar van te hoë teksdigtheid geld in ' $n$ nog groter mate die gerekenariseerde woordeboek. 'n Gerekenariseerde omvattende en meerdoelige woordeboek soos die WAT laat om verskeie redes nie altyd dieselfde teksverdigting toe as 'n ongerekenariseerde woordeboek nie. Dit het te doen met die feit dat daar by die rekenarisering van 'n woordeboekprojek ook ander woordeboekanwendings en gevolglike toeganklikheidsvereistes as die konvensionele in die spel kom. Die belangrikste vereiste is dat daar in die aanbod van aangawes voorsiening gemaak moet word vir die eventuele onttrekking van inligting per rekenaar. Elke inligtingstipe (bestaande uit een of meer aangawes) moet nog volkome deursigtig wees wanneer dit eenmaal binne of buite sy rekenaarinskrywingsveld van die omringende teks geïsoleer is. Dit geld byvoorbeeld waar hierdie inligting vir taalnavorsingsprojekte, die samestelling van kleiner satellietwoordeboeke of vir die aanwending in 'n elektroniese woordeboek met skermtoegang onttrek word.

'n Aangawe kan uit een of meer inskrywings en selfs uit verskillende samestellende aangawes bestaan (Wiegand 1989b: 428 e.v.). So byvoorbeeld word die sinonieme en alle teks wat die sinonieme as sodanig ekspliseer en gevolglik van die ander aangawes help onderskei, tot die aangawe SINONIEME gereken, terwyl elkeen van die elemente waaruit die aangawe saamgestel is, inskrywings genoem word waarvan sommige ook weer aangawes oftewel deelaangawes kan wees. ' $n$ Voorbeeld uit WAT deel IX sal dit illustreer:

lyf s.nw., lywe; lyfie.

1 Fisieke geheel waaruit ' $n$ mens bestaan; dikw., in minder formele verband, sin. met liggaam en soms met korpus: Fris, groot, swaar, skraal van lyf. [...]

Die hele teksgedeelte van "dikw." tot "korpus" vorm die aangawe SINONIEME. Die sinonieme liggaam en korpus is elk 'n deelaangawe. Die inskrywing "sin." tree as eksplisiete merker van hierdie deelaangawes se sinoniemstatus op en vorm soos elk van die ander kwalifikasies een van die samestellende inskrywings van hierdie aangawe. Die inskrywing "soms met" is ' $n$ merker wat alleen op korpus slaan en inligting oor die gebruiklikheid daarvan verskaf.

Alle aangawes wat uit deelaangawes bestaan, en waarvoor die Buro van die WAT vanaf WAT deel IX voorsiening maak, sal saam met ander woordeboekinligtingstipes (oftewel woordeboekinskrywingstipes) voortaan in hierdie artikel bloot inligtingstipes (oftewel inskrywingstipes) genoem word, tensy ander oorwegings geld. Dieselfde geld die deelaangawes, met ander woorde: tensy oorwegings ter onderskeiding geld, sal hulle bloot aangawes heet. Verder geld dat inligtingstipe in hierdie artikel kan verwys na een aangawe of meer as een verwante aangawes wat onderskeidelik alleen of saam aangebied 
word om 'n bepaalde soort inligting te verstrek.

Daar moet in gedagte gehou word dat alle aangawes en deelaangawes woordeboekinligtingstipes en tewens woordeboekinskrywingstipes verteenwoordig (nie omgekeerd nie). Daarom kon daar onder afdeling 2.4 hier bo gesê word dat woordeboekinligtingstipe en woordeboekinskrywingstipe in hierdie artikel gewoonlik verkort word tot onderskeidelik inligtingstipe en inskrywingstipe. Anders gestel: aangawes is altyd ook woordeboekinligtingstipes en laasgenoemde is altyd ook inligtingstipes; maar inligtingstipes (in die algemeen, dit wil sê ook buite die leksikografie gesien) is nie altyd woordeboekinligtingstipes nie en laasgenoemde is ook nie altyd aangawes nie.

Sien Skema 2 onder Bylaes vir 'n kort uiteensetting van die aangawe.

\section{STRUKTUURAANWYSERS}

'n Struktuuraanwyser of struktuurmerker (Engels structural marker / structural indicator; Duits Strukturanzeiger) is enigeen van 'n verskeidenheid woordelysinskrywings waarvan die ware doel is dat hulle die woordeboekgebruiker help om aangawes beter te identifiseer en sistematies op te spoor ten einde die inligting daarin vinniger te ontsluit (Wiegand 1989b: 428; 433 - skematiese voorstelling). Die gemelde ware doel van die struktuuraanwyser onderskei dit van daardie aangawe wat benewens inhoudsgerig ook struktuurgerig kan wees maar nooit slegs struktuurgerigtheid as ware doel (oftewel primêre funksie) het nie.

Alhoewel struktuuraanwysers se funksie altyd op die artikelstruktuur gerig is en hulle gewoonlik binne die artikel aangetref word, kan hulle volgens Hausmann en Wiegand (1989: 335) ook buite die artikel in die woordelys voorkom. Hiervan is die indeksletters A, B, C, ensovoorts, voor die onderskeie alfabetiese seksies van die woordeboek goeie voorbeelde.

Aangesien struktuuraanwysers sowel binne as buite die artikel kan voorkom, word hier voorgestel dat daar tussen die interne struktuuraanwyser (Engels inner structural marker / inner structural indicator; Duits innerer Strukturanzeiger) en die eksteme struktuuraanwyser (Engels outer structural marker of outer structural indicator; Duits äußerer Strukturanzeiger) onderskei word.

Omdat daar soms na bepaalde struktuuraanwysers as "funksionele merkers" verwys word (vergelyk Kruyt en Van der Voort 1992: 205 se gebruik van "functional mark"), beteken dit nie dat "funksionele merker" of "funksionele inskrywing" goeie alternatiewe terme vir "struktuuraanwyser" vorm nie aangesien alle inskrywings, insluitend aangawes, volgens Hausmann en Wiegand (1989: 330 e.v.) funksioneel behoort te wees. (Vergelyk afdeling 2.1 hier bo vir die interpretasie wat hier in ooreenstemming met Wiegand 1989b: 425 aan die term "funksioneel" geheg word.) Aangawes is volgens die definisie hier bo nie struktuuraanwysers nie. Dit geld selfs aangawes in die vorm van simbole wat benewens die verskaffing van woordeboekinligting ook toegangstrukture sou 
kon aandui (die sogenaamde "Angabesymbolen für Markierungsangaben" Wiegand 1989b: 430). Alternatiewe terme soos "funksionele merker" en "funksionele inskrywing" onderskei dus nie tussen struktuuraanwysers en aangawes van watter aard ook al nie en moet daarom verwerp word.

Struktuuraanwysers kan in verskeie klasse onderverdeel word waarvan die volgende twee die belangrikste is:

\subsection{Tipografiese struktuuraanwysers}

Tipografiese struktuuraanwysers is grafiese middele wat die teks of teksgedeeltes van bepaalde aangawes visueel met dié van ander aangawes laat kontrasteer. Voorbeelde hiervan is onderskeidende onderstreping, kursief- en vetdruk, hoofletter- en kleinhoofletterdruk, verhewe skrif en druk in verskillende lettersoorte (onder andere skreef-en skreeflose letters). Selfs die blanko ruimte (Engels blank space; Duits Leerzeichen) dien as 'n belangrike tipografiese struktuuraanwyser (Wiegand 1989a: 375). Die kontrasterende teks geld hier telkens as tipografies gemerk terwyl die gewone teks as tipografies ongemerk beskou word.

Om te illustreer hoe tipografiese struktuuraanwysers met aangawes kombineer en hulle ondersteun, kan verwys word na die volgende in die WAT gebruiklike hiërargiemerkers': I, II, III (wat woordsoortelike funksies aandui); en $1,2,3 ; a, b, c ; i$, ii, iii; $\alpha, B$ of kombinasies daarvan, byvoorbeeld 1 a en $3 \mathrm{~b}$ ii $\mathrm{B}$ (wat betekenisonderskeidings aandui); asook ' $\mathrm{n}$ kombinasie van die hiërargiemerkers vir woordsoortelike funksies aan die een kant en betekenisonderskeidings aan die ander kant, byvoorbeeld I 4; I 5 a; II 3 c iv $\alpha$ (wat betekenisonderskeidings binne bepaalde funksieafdeling aandui). Dit is almal aangawes - nie struktuuraanwysers nie - wat as sodanig nie baie opvallend vertoon nie. Deur hulle van tipografiese struktuuraanwysers in die vorm van vetdruk te voorsien, val hulle aansienlik sterker op. Die resulterende vet I, II, III; $1,2,3$; ensovoorts, is nou weliswaar elk 'n kombinasie van 'n aangawe en 'n

2 In die hiërargiese strukturering of geleding van sy artikels gebruik die Buro van die WAT Arabiese syfers (1, 2, 3), alfabetiese karakters (a, b, c), Romeinse syfers (1, II, III en i, ii, iii) en Griekse alfabetiese karakters $(\alpha, B)$ of 'n kombinasie daarvan, byvoorbeeld I 3 a it $\alpha$. Omdat nie al hierdie karakters binne die sogenaamde alfameriese of alfanumeriese indeling., geleding- of "nommering"-stelsel as "nommers" bestempel kan word nie, sal daar vervolgens, waar nodig geag, na hulle gesamentlik as hiërargiemerkers verwys word. In die rekenaarleksikografie en veral binne die Buro se rekenaarveldstruktuur vir inligtingstipes staan hulle as artikelvlakmerkers bekend. 'n Bykomende rede vir die voorkeur vir hiërargiemerkers en artikelvlakmerkers bo "betekenisnommers" is dat die hiërargiese strukturering van die artikel nie alleen met die indeling in betekenisonderskeidings te doen het nie, maar ook met die indeling in onder andere woordsoortelike funksies. Anders gestel: die hiërargiemerkers dui alle soorte artikelvlakke aan. 
tipografiese struktuuraanwyser maar bly primêr 'n aangawe. Die vetdruk hef eersgenoemde se status dus nie op nie maar ondersteun dit bloot. Sien ook Wiegand (1989b: 450) hieroor.

\section{2}

\section{Nietipografiese struktuuraanwysers}

Nietipografiese struktuuraanwysers is fisiese karakters wat verskillende soorte aangawes of hulle komponente merk, hulle van mekaar skei of tot 'n eenheid bind. Voorbeelde hiervan is skeidingstekens soos die komma en kommapunt, bindingstekens soos die verskillende soorte hakies, grafiese karakters soos die aandagstreep, die soliede vierkantige blokkie en verskillende tiperende simbole. Hulle dien as aanwysers of merkers van 'n bepaalde strukturele ordening in die aanbod van die aangawes. Gerzymisch-Arbogast (1989: 950 e.v.) gee nie alleen 'n verdere tipering van hierdie klas struktuuraanwysers nie maar ook 'n skematiese voorstelling van hulle aanwending en funksies.

Die komma, kommapunt en aandagstreep se optrede as struktuuraanwysers moet onderskei word van hulle optrede as gewone interpunksietekens. Wiegand (1989b: 428) verduidelik die verskil soos volg: "Strukturanzeiger operieren auf der Ebene der Wörterbuchform, Interpunktionszeichen auf der des Wörterbuchgegenstandes." Anders gestel: Eersgenoemde onderskei verskillende soorte aangawes; laasgenoemde onderskei veral sintaktiese geledinge in die woordeboekteks.

Verder moet die hiërargiemerkers $\mathbf{a}, \mathbf{b}, \mathbf{c}$ voor betekenisonderskeidings onderskei word van die indeksletters A, B, C voor die alfabetiese seksies van 'n woordeboek. Eersgenoemde is aangawes en kan slegs binne die artikel voorkom, terwyl laasgenoemde nietipografiese struktuuraanwysers is wat weer buite die artikel staan en deel van die woordelys uitmaak. Die soliede swart kolletjies en blokkies asook die gegolfde =-teken wat die Buro in WAT deel IX as merkers van sekere inligtingskategorieë binne die artikel ingevoer het, is ook nietipografiese struktuuraanwysers. Hulle moet weer onderskei word van ander simbole binne die artikel, byvoorbeeld 'n motortjie, musieknoot of tandrat, wat in sekere, veral tegniese, woordeboeke as merkers in die plek van gebruiksetikette diens doen en as aangawes beskou word. Merkers soos die swart kolletjie is struktuuraanwysers omdat hulle verskillende soekareas (Engels search areas; Duits Suchbereiche) skei waarbinne die gebruiker die verlangde aangawes kan soek (Hausmann en Wiegand 1989: 338). Merkers soos die motortjie en musieknoot is aangawes omdat hulle leksikale begrippe voorstel en in eie reg gebruiksinligting verstrek.

Wiegand (1989b: 428) wys daarop dat nietipografiese struktuuraanwysers soos die komma en die kommapunt (albei in die hoedanigheid van skeidingstekens) nie self aangawes vorm nie maar wel binne aangawes kan optree.

Sien Skema 3 onder Bylaes vir 'n kort uiteensetting van die struktuuraanwyser. 


\section{TOEGANGSTRUKTUUR}

Wiegand (1989a) asook Hausmann en Wiegand (1989) sit slegs twee soorte artikelinskrywings uiteen, naamlik aangawes en struktuuraanwysers. Hier bo is aangetoon dat hulle onderskeidelik ten dele en in die geheel sterk struktuurgerig (oftewel vormgerig) is. Hierdie struktuurgerigtheid is nie alleen medebepalend vir die mikro- en makrostruktuur van die woordeboek nie maar ook vir die ontsluiting van die inligting wat opgeneem is.

Wiegand (1989a: 393) sê dat die makrostruktuur in 'n woordeboek een of meer verskillende deelstrukture in die vorm van woordelyste kan hê. Elk van hierdie deelstrukture is ' $n$ op die gebruiker gerigte ordening- en aanbiedingsisteem vir woordeboekinligting en word 'n toegangstruktuur genoem. Die toegangstruktuur is identies aan die makrostruktuur wanneer die woordeboek uit slegs een deelstruktuur van dié aard bestaan (Hausmann en Wiegand 1989: 329). Die WAT is so ' $n$ woordeboek met slegs een makrostrukturele deelstruktuur oftewel woordelys ${ }^{3}$. Wanneer ' $n$ woordeboek twee of meer makrostrukturele deelstrukture bevat, word gesê dat hy twee of meer toegangstrukture maar slegs een oorkoepelende makrostruktuur het.

Met die keuse van die term toegangstruktuur word daar besondere klem op 'n belangrike inherente funksie van elke makrostrukturele deelstruktuur geplaas: dit is dat dié struktuur in 'n beduidende mate help om die woordeboekgebruiker vinnig by die einddoel, die inligting wat in die aangawes vervat is, uit te bring. Kennis van 'n woordeboek se toegangstruktuur vergemaklik naamlik die sistematiese opsoek van aangawes (Wiegand 1989a: 393) omdat die gebruiker dan weet waar om hulle relatief binne die artikel te vind. Dit geld natuurlik slegs as die redaksie hom by die samestelling van die woordeboek konsekwent aan hierdie struktuur hou. Anders gestel: Die toegangstruktuur bepaal die soekroete (Engels search path; Duits Suchpfad) in die woordeboek (vergelyk Hausmann en Wiegand 1989: 338).

Daar word onderskei tussen die eksterne en die interne toegangstruktuur (Wiegand 1989a: 393). Die eksterne toegangstruktuur (Engels outer access

In beginsel is dit juis; in die praktyk klop dit nie altyd nie aangesien daar in die meeste WAT-dele een, soms twee، aparte woordelyste in die agterwerk opgeneem is, byvoorbeeld "Voorlopige Byvoegsel" (in die agterwerk van WAT deel I) en "Verbeteringe in deel II van die Afrikaanse Woordeboek wat in die tweede oplaag daarvan reeds aangebring is" (in die agterwerk van WAT deel III). Hulle verteenwoordig telkens die aanvulling van leemtes en die regstelling van foute in dieselfde en/of die voorafgaande deel. Hierdie bykomende woordelyste moet deur die gebruiker in die sentrale woordelys van die betrokke woordeboekdeel geïntegreer of ingedink word. Met ander woorde hulle moet tot dieselfde makrostruktuur as die as die alfabeties ooreenstemmende sentrale woordelys gereken word. In 'n heruitgawe van die WAT-dele sal die aparte woordelyste almal verval omdat die inskrywings dan fisies deur die redaksie op die bedoelde plekke in die sentrale woordelys opgeneem sal wees. 
structure; Duits äußere Zugriffsstruktur) is die toegangstruktuur (soos hier bo gedefinieer) van alles wat buite die mikrostruktuur geleë is (gevolglik met insluiting van die lemmas en die homoniemnommers) en wat die gebruiker in sy soekroete tot by die lemma lei. Die interne toegangstruktuur (Engels inner access structure; Duits innere Zugriffsstruktur) is die toegangstruktuur van alles wat in die mikrostruktuur geleë is en die gebruiker in sy soekroete tot by die aangawes lei. Wiegand (1989a: 393) wys daarop dat die interne toegangstruktuur nie 'n deelstruktuur van die eksterne toegangstruktuur is nie. Hausmann en Wiegand (1989: 339) gee 'n duidelike grafiese tipologie van toegangstrukture, sodat dit nie nodig is om hier meer oor die algemene aard daarvan te sê nie.

\section{TOEGANGSINSKRYWINGS}

Dit is opvallend dat Hausmann en Wiegand (1989: 338-339) en Wiegand (1989a: 394 e.v.) baie aandag bestee aan die toegangstruktuur self en aan die toegangsroete wat dit tot die woordeboekinligting verskaf. Hulle identifiseer daarteenoor blykbaar geen behoefte om alle woordeboekinskrywings wat primêr of sekondêr 'n toegangsfunksie het (oftewel ontsluitend van aard is) en wat tot verskillende woordeboekstrukture behoort, tog wel op grond van hulle gemeenskaplike ontsluitingsfunksie saam in een aparte kategorie van inligtingontsluitende inskrywings te plaas en as sodanig te behandel nie.

In die rekenaarleksikografie kry 'n mens verskeie eiesoortige inskrywings wat deur die rekenaar in sy soektogte gebruik kan word om artikelinligting mee te identifiseer, byvoorbeeld vir dataonttrekking. Daarom bestaan daar veral in dié vertakking van die leksikografie 'n groot behoefte aan 'n omvattende term vir al daardie inskrywings wat die ware doel het om die aangawes toeganklik te maak en te help ontsluit, met ander woorde ook vir al daardie inskrywings wat meehelp om die eksterne en interne toegangstruktuur van die woordeboek te bepaal. Hier onder sal so 'n term aan die hand gedoen en verskillende subkategorieë van dié inskrywingsoort dan op grond van nuwe onderskeidingsbehoeftes benoem en bespreek word.

Daar is reeds in afdeling 2.2 hier bo aangedui dat die duimindeks, indeksletters en sleutelwoorde volgens Hausmann en Wiegand (1989: 330 e.v.) almal funksionele woordelysinskrywings is, nieselfstandige tekste uitmaak en vergelykbare funksies het. Ten spyte hiervan word hulle nie met ' $n$ gemeenskaplike term aangedui nie. Die rede is waarskynlik dat hulle tot twee verskillende struktuurtipes behoort:

Die duimindeks en die sleutelwoorde is deel van die eksterne kitstoegangstruktuur (Engels outer rapid access structure; Duits äußere Schnellzugriffsstruktur) en verteenwoordig gidselemente (Engels guiding elements; Duits Leitelemente) in die soekroete van die woordeboek (Hausmann en Wiegand 1989: $333,335,338$ ). 
Die indeksletters, daarenteen, is nie elemente van die toegangstruktuur nie en verteenwoordig eksterne struktuuraanwysers (Hausmann en Wiegand 1989: 335, 338).

Daar word gevolglik voorgestel dat toegangsinskrywing (of ontsluitingsinskrywing) (Engels access entry / access item; Duits Aufschlüsselungseintrag) as so 'n omvattende term in die metaleksikografie gebruik word. (Vergelyk ook Gerzymisch-Arbogast 1989: 950 se gebruik van "Aufschlüsselung".) 'n Toegangsinskrywing is dan enige funksionele woordeboekinskrywing wat die gebruiker of die rekenaar direk of indirek help om bepaalde aangawes in die woordeboek te identifiseer ten einde die bedoelde inligting daaraan te kan onttrek.

Die invoer van die term hoef nie die aard en status van die verskillende struktuurtipes en inskrywingstipes wat daardeur gedek word, wesenlik te verander nie. Dit vereenvoudig wel die naamgewing op 'n bepaalde aanwendingsterrein, in die besonder op die terrein van die rekenaarleksikografie.

'n Toegangsinskrywing kan, soos in onderstaande subkategorieë aangetoon sal word, hoofsaaklik enigeen van die volgende wees: 'n struktuurgerigte aangawe, 'n struktuuraanwyser, 'n kombinasie van die twee, enige ander inskrywing wat slegs deur die rekenaar as hulpmiddel gebruik word (byvoorbeeld as identifikasiemerker), asook toeligtende, identifiserende en motiverende kommentaar. Hierdie inskrywings bly primêr ook deel van die kategorieë waaronder hulle tradisioneel, soos hier bo bespreek, ingedeel word. Hulle word vervolgens bloot in bykomende en nuwe funksies aangewend.

Die term toegangsinskrywing vind sy regverdiging onder andere ook daarin dat dit in die rekenaarleksikografie as sodanig nie meer so belangrik is of die woordeboek in boekvorm of in elektroniese vorm gepubliseer sal word nie; so iets is bloot afhanklik van ' $n$ redaksionele besluit. Wat wel belangrik is, is dat die woordeboek só op rekenaar gekonsipieer word dat dit vir albei voorsiening maak. Databasisse word nie meer net een maal gebruik nie maar by herhaling. Dit is die gedagte agter die sogenaamde "open end"-databasis. ' $n$ Belangrike uitspraak in dié verband is: "[A]n important change of perspective was required: if dictionary data are to be exploited for several purposes, the electronic form of the dictionary should no longer be considered a spin-off of the printed form, but rather the other way around" (Masereeuw en Serail 1992: 258). Hierdie moderne opvatting van die leksikografie vra daarom ook om 'n oop en omvattende terminologie wat vir enige aanwending van die woordeboekdatabasis toepaslik is.

Die toegangsinskrywings kan ooreenkomstig hulle belangrikste of "primêre" aanwending (as gedeeltelik nuwe inskrywingstipe) in twee subkategorieë ingedeel word, naamlik dié wat deur die gebruiker van die woordeboek in gedrukte vorm benut word om inligting te ontsluit en dié wat deur die rekenaar benodig word om inligting in die elektroniese woordeboekteks te identifiseer met die oog op dataonttrekking, byvoorbeeld in die voorbereiding van 'n gedrukte of ' $n$ elektroniese weergawe van ' $n$ woordeboek of enigeen van sy satel- 
lietprodukte. Hierdie subkategorieë heet onderskeidelik die gebruikertoegangsinskrywings en die rekenaartoegangsinskrywings.

Sien Skema 4 onder Bylaes vir 'n kort uiteensetting van die toegangsinskrywing.

\subsection{Gebruikertoegangsinskrywings}

Enige woordeboekinskrywing wat die toegangstruktuur bepaal, word hier in aansluiting by Hausmann en Wiegand (1989: 337 e.v.) se siening van die toegangstruktuur die gebruikertoegangsinskrywing genoem (Engels user access entry of user access item; Duits Zugriffseintrag of Zugriffssegment of, binne die hier voorgestelde terminologiese skema, Benutzeraufschlüsselungseintrag).

Gebruikertoegangsinskrywings is al daardie woordeboekinskrywings wat die gebruiker help om vinniger toegang tot die aangawes in die gedrukte woordeboek te verkry. Dit spreek ook hier vanself dat die vinniger toegang tot die aangawes verlang word ten einde die inligting wat daarin vervat is, makliker te ontsluit. Hierdie subkategorie van die ontsluitingsinskrywings is hoofsaaklik maar nie uitsluitlik nie, soos later sal blyk, saamgestel uit alle struktuuraanwysers en alle struktuurgerigte (oftewel vormgerigte) aangawes soos hier bo uiteengesit en kan dienooreenkomstig ruweg ingedeel word in die tipografiese en nietipografiese, die leksikale en nieleksikale gebruikertoegangsinskrywings. Die term gebruikertoegangsinskrywing slaan onder andere op sowel die eksterne as die interne struktuuraanwysers in die woordeboek.

Dit is duidelik dat alle gebruikertoegangsinskrywings die toegangstruktuur dien. Volgens Hausmann en Wiegand (1989: 333) maak hulle egter nie almal self deel van die toegangstruktuur uit nie. As voorbeeld noem hulle die struktuuraanwysers A, B, C, ensovoorts. Daar kan sonder twyfel aanvaar word dat hierdie indeksletters (wat voor die onderskeie alfabetiese seksies van die woordeboek staan en, soos reeds aangedui, daarom nie deel van die artikelstruktuur kan wees nie) tot die woordelysstruktuur behoort. 'n Saak kan egter verder daarvoor uitgemaak word dat hulle wel ook elemente van die toegangstruktuur vorm. Dit kan miskien die maklikste gedoen word deur op ' $n$ moontlike inkonsekwentheid in Hausmann en Wiegand (1989) se eie argumentering hieroor te wys:

Aan die een kant beweer hulle (1989: 333): "The elements ' $Y=I$ ', ' $Y=J$ ', ' $Z$ ' [...] are neither elements of the microstructure nor elements of the macrostructure nor of the access structure". Aan die ander kant sê hulle (1989: 335): "The bold face capitals A, B, ..., $Z$ are structural indicators [...]. The structural indicators represent the access alphabet of the dictionary". Die stelling dat die indeksletters behoort tot die "access alphabet" maar nie tot die "access structure" nie, wek reeds die vermoede van 'n benoemingsprobleem. Hierdie vermoede word kort daarna (1989: 335) bevestig waar hulle dit het oor die woordeboek se duimindeks (' $n$ stel indeksletters wat van buite die geslote boek sigbaar is) en 
dan praat van "a thumb index [...] which is a rapid access structure". Nog 'n entjie verder (1989: 338), waar dit oor sowel die deurloopteks (onder andere die sleutelwoorde) as die duimindeks handel, stel hulle dit pront: "Together the running heads of the dictionary form the outer rapid access structure. [...] Some dictionaries have a second rapid access structure, namely the thumb index."

Of die metaleksikograwe inderdaad die indeksletters as deel van die (eksterne) toegangstruktuur beskou, soos dit die geval met die duimindeks en die sleutelwoorde is, raak nie die benaming en benutting daarvan as gebruikertoegangsinskrywings nie. Daar moet verder op gewys word dat hoewel die rekenaar ook etlike van die gebruikertoegangsinskrywings in sy soektogte kan gebruik, sal dit nog nie ware rekenaarontsluitingsinskrywings van hulle maak nie.

Hier onder word enkele voorbeelde van gebruikertoegangsinskrywings binne die belangrikste kategorieë gegee.

\subsubsection{Leksikale gebruikertoegangsinskrywings}

Alle struktuurgerigte leksikale aangawes kan ook as leksikale gebruikertoegangsinskrywings optree. Hulle help die gebruiker om die inhoudsgerigte aangawes makliker te vind. Hulle speel daarom ' $n$ groot rol in die voorkoming van ' $n$ te hoë teksdigtheid. In die WAT verrig die volgende tipiese interne inskrywings so 'n funksie:

Die opskrifte "UITDR. IDIOMATIES" bo die betrokke rubriek en die soekwoord "Donderdagnag" voor die idiomatiese uitdrukking "so lelik soos Donderdagnag (om) twaalfuur", byvoorbeeld:

\section{UITDR. IDIOMATIES}

Donderdagnag: so lelik soos Donderdagnag (om) twaalfuur Uiters lelik. [Onder lelik.];

die aanloop "Ook fig." voor die sitaat wat die figuurlike toepassing van die leksikale item illustreer, byvoorbeeld:

- Ook fig.: Die son speel-speel so luilekker deur die jakarandatakke (E. Spence: Kaleidoskoop, 1970, 1).

[Onder luilekker.];

die eksplisiete "sin." voor die vermelding van die sinoniem self, byvoorbeeld:

sin. laringaal

[klank: laringale klank onder laringaal I.]; 
sowel die opskrif "OPM." as die inhoud van die opmerking self wat 'n aangawe toelig, byvoorbeeld:

OPM. Dit is mntl. dat met leeg, wanneer dit i.v.m. die see(water) gebruik word, ${ }^{1}$ leeg bedoel word. Hierdie gevalle is dan nie wisselvorme van laag nie. Vgl. LEEGWATER, opm.

[Onder ${ }^{2}$ leeg I.].

Wat laasgenoemde betref, meld Hausmann en Wiegand (1989: 342) dat die gebruik van opmerkings in die leksikografie toeneem en dat daarmee na groter gebruikersvriendelikheid gestreef word deurdat opmerkings gewoonlik uit maklik leesbare teks binne die gewoonlik hoogs verdigte teks van die artikel bestaan.

Ook eksterne leksikale of deels leksikale inskrywings in die WAT verrig soms so 'n toegangsfunksie. Die bekendste is die sleutelwoord boaan elke bladsy. Hulle bestaan nie altyd net uit leksikale teks nie. Dikwels verskyn daar 'n hiërargiemerker (nommer) by wat die sleutelwoord aan die betrokke betekenisonderskeiding van die artikel koppel, byvoorbeeld: "KOMMUNIKASIE, 1 a ii $\alpha$ " (WAT deel VII); "LIG I, uitdr." (WAT deel LX).

Die sleutelwoord self wys hier dan na die lemma in die makrostruktuur heen, terwyl die hiërargiemerker op 'n betekenisonderskeiding in die mikrostruktuur slaan. Sleutelwoorde en gevolglik ook die gidselemente kan die gebruiker daarom sowel na aangawes in die makrostruktuur as na aangawes in die mikrostruktuur toe lei.

\subsubsection{Nieleksikale gebruikertoegangsinskrywings}

Alle nieleksikale aangawes kan ook as nieleksikale gebruikertoegangsinskrywings optree. Die mees tipiese voorbeelde hiervan is illustrasies, tabelle, simbole en formules wat deel van die artikel vorm en die gebruiker help om aangawes soos die definisie makliker te ontsluit. Ook hulle speel 'n groot rol in die voorkoming van 'n te hoë teksdigtheid.

In WAT deel VII het inskrywings soos die molekulêre struktuur binne die definisie van die artikel klavasien en in mindere mate die illustrasies by klaphaak en kleurpiramide 'n ontsluitings- of toeligtingsfunksie. Die kleurplate by kleuromskrywing en die illustrasie van alle soorte knope by knoop ${ }^{1}$ in dieselfde WAT-deel is weer besonder ensiklopedies van aard.

Hier word vir ' $n$ wye toepassing van die term toegangsinskrywing gepleit. Volgens hierdie ruim aanwending hoef die gebruikertoegangsinskrywings ook nie net tot die artikel of die woordelys beperk te wees nie; hulle moet wel die inligting in die artikel of artikels help ontsluit. Hulle is dus altyd struktuurgerig ten opsigte van artikelinskrywings. Illustrasies in die voorwerk vertolk in dié opsig 'n besonder interessante rol as nieleksikale gebruikertoegangsinskrywings. 'n Afbeelding van 'n tipiese artikel uit die woordelys, veral 
een wat voorsien is van byskrifte (dit wil sê van leksikale gebruikertoegangsinskrywings) om die verskillende inligtingstipes in so 'n artikel uit te wys en toe te lig, kan waardevolle inligting vir die ontsluiting van alle artikels in die woordelys bied. In die voorwerk van Webster en WAT IX word sulke nuttige toegangsinskrywings aangebied.

Die illustrasies in die voorwerk van die WAT het nie altyd 'n ontsluitingsfunksie nie: die kleurplate van die vlae in verband met die Suid-Afrikaanse geskiedenis voor in deel II (D-F) hou geen verband met enige inskrywing in die woordelys nie - geeneen van die vlagname begin byvoorbeeld met die letters $\mathrm{D}$ tot $\mathrm{F}$ nie. Ook dit verteenwoordig dus ensiklopediese inligting. Anders gestel: dit is 'n niefunksionele voorwerkinskrywing aangesien sy funksie glad nie vir die woordelys van die betrokke woordeboek ter sake is nie. Trouens, volgens Wiegand (1988: 770) is so 'n inskrywing ook nie eers ensiklopedies funksioneel nie omdat dit 'n woordeboekinskrywing uitmaak "dem der Lexikograph als Ganzem keinen genuinen Zweck zugeordnet hat".

\subsubsection{Tipografiese gebruikertoegangsinskrywings}

Tipografiese gebruikertoegangsinskrywings is almal primêr ook struktuuraanwysers. Die mees tipiese voorbeeld hiervan is die onderskeidende formatering van karakters en paragrawe. Karakters kan byvoorbeeld in vet-, kursiewe, verhewe druk, onderstreep en in kleinhoofletters geplaas word; paragrawe kan in- of uitspring. Ook die blanko ruimte speel in die reël 'n belangrike rol in die tipografie, ofskoon dit in sekere gevalle ook as een van die "alphabetexternen Buchstaben" (Wiegand 1989a: 375 en 380) en dus as 'n nietipografiese struktuuraanwyser of gebruikertoegangsinskrywing gesien sou kon word. Wiegand (1989a: 385) tipeer die tipografiese funksie van vetdruk en blanko ruimtes soos volg: 'Die Eigenschaft 'halbfett' wirkt strukturanzeigend: ein neuer Wörterbuchartikel (hier zugleich ein neuer Textblock) beginnt; der Abbruch der letzten Zeile des Artikels (und damit die - meistens - leere Textzeile bis zum Zeilenende) wirkt ebenfalls strukturanzeigend."

Die tipografiese gebruikertoegangsinskrywing kombineer met en ondersteun al die ander soorte inskrywings, byvoorbeeld in die artikelstruktuur. Dit moet nie as ' $n$ eksterne toevoeging tot die teks gesien word nie maar as 'n integrale deel van die woordeboekstruktuur. Anders gestel: die ondersteuning wat tipografiese gebruikertoegangsinskrywings aan ander inskrywings bied, vorm deel van 'n teksinterne samehang. Die ware doel daarvan is dat dit die gebruiker help om aangawes soos die lemma en die sitate makliker te identifiseer vir ontsluiting. Omdat hulle konvensionaliseerbaar en grootliks selfs reeds gestandaardiseer is, speel hulle ook 'n belangrike rol in die voorkoming van 'n te hoë teksdigtheid. 


\subsubsection{Nietipografiese gebruikertoegangsinskrywings}

Nietipografiese gebruikertoegangsinskrywings bestaan uit alle nietipografiese struktuuraanwysers, alle struktuurgerigte aangawes en enkele ander soorte inligtingontsluitende inligtingstipes in die woordeboek. Die mees tipiese voorbeelde hiervan word deur Hausmann en Wiegand (1989: 344) saamgevat as "figures, letters, brackets, punctuation marks, symbols." In die WAT is dit op mikrostrukturele vlak (intern) onder andere die twee soorte hakies (), [] (vergelyk egter die hakies $\langle>, 0$ en $a$ in afdeling 6.2 .1 hier onder); betekenisnommers en ander hiërargiemerkers soos 1, 2, 3; a, b, c; I 1 a, 2 b; die streep wat 'n koppeltekenlemma aandui; die kommapunt, dubbelpunt; swart kolletjies en blokkies en die a-teken. Buite die artikelstruktuur (ekstern) is dit die indeksletters A, B, C voor die alfabetiese seksies binne die woordelys.

Tot die nietipografiese gebruikertoegangsinskrywings en gedeeltelik die leksikale gebruikertoegangsinskrywings moet ook die kort kieslys (binne die mikrostruktuur) gereken word van al die betekenisonderskeidings wat in die betrokke artikel volg. Dit word teenswoordig al meer in veral aanleerderwoordeboeke opgeneem om die gebruiker te help in sy keuse van die betekenisonderskeiding wat hy soek. Die hiërargiemerkers in die kieslys stem met die hiërargiemerkers van die betekenisonderskeidings ooreen; hulle verteenwoordig die nietipografiese gebruikertoegangsinskrywings. Die teks daarby vat byvoorbeeld die definisies kripties saam; hulle verteenwoordig weer die leksikale gebruikertoegangsinskrywings. Vergelyk in dié verband Tono (1992).

Van Sterkenburg (1976: 101) beveel die kieslys, of wat daarop neerkom, selfs selektief vir omvattende woordeboeke aan: "Richt de artikelen doorzichtig in en geef een inhoudsopgave bij grotere artikelen." Woordeboeke soos die WAT en die WNT sou dié gebruik inderdaad op groter skaal by langer artikels kon oorweeg. Laasgenoemde het dit byvoorbeeld nagelaat by WIJD (I), wat oor 65 kolomme strek, ofskoon die hiërargiemerkers A), B), C) en D) voor elkeen van dié afdelings hulle uitstekend tot so ' $n$ inhoudsopgawe of kieslys leen. Selfs net húlle saamgevoegde opname heel aan die begin van die artikel sou die inligting daarin makliker ontsluit het. A) lui byvoorbeeld'soos volg:

A) In tweedimensionalen zin in toep. op een oppervlakte met als kernbet. 'uitgestrekt', en in daarby aansl. gebr.

Die WAT gee hierdie kieslys baie sporadies vooraan langer artikels, byvoorbeeld by kom $^{2}$ I in deel VII. Dié voorbeeld vertoon egter tipografies nie opvallend genoeg nie en die inhoud kon kriptieser en baie eenvoudiger gestel gewees het. Trouens, soos dit nou daar staan, werk dit eerder begripsverswarend as begripsverhelderend en bevorder daarom nie die toeganklikheid van die woordeboek nie. 'n Deel van hierdie artikel volg hier onder saam met afbeeldings van twee geslaagde kieslyste uit Japans-Engelse aanleerderwoordeboeke (Tono 1992: 240). 
$k^{2}$. I w., komend(c); gekom of soms (veroud. en (of) digr.) gekome; byv. (gew. altr.) en byw. komend(e), gekome. I/d alg., selfstandig beweeg of, passief, gebring word (lett. of fig. in talryke bepalende verbande) na in eind-, doel- of waarnemingspunt, gesien vanuit die punt, of ook, gesien $i / d$ rigting $v / d$ beweging uit die gesigspunt $v / d$ bewegende-gebruik as selfst. ww. (meestal onoorganklik), as hulpw. (bet. I. C. 2) of ook soms, in verswakte sin, as koppelw. (bet. I, C, 3), met beklemtoning in meerdere, mindere of gemengde mate van A. die beweging van nadering self in sy voonduring. gew. as iets wat a/d gang is, aanhoudend herhaal word of gebruiklik is, hom altyd so voordoen (duratiewe aspek). B. die beginpunt (soms in punt onderweg), of die rigting waaruit die beweging plaasvind (inchoatiewe aspek), of, veral, C. die eindpunt (soms in punt onderweg), of die rigting waarin die beweging plaasvind (perfektiewe aspek); dikw. teenoor gaan.

A. (met beklemtoning van 'n beweging van nadering in sy vooriduring) 1. a. Selfstandig, of as sodanig voorgestel, nader beweeg, onderweg, in aantog wees [soos bepaal] of, passief, so gebring, vervoer word-gesê $\mathrm{v} / \mathrm{d}$ beweging van persone, diere, sake, oorwegend in ruimtelike sin; van ' $n$ ongebore kind-verwag word: Ons kom al en sal nou-nou daar wees. Ons kom al 'n hele ent, en dit word tyd' om te rus. Hy kom altyd per motor. Al my gued kom per spoor. Met volle vaart, wit alle mag kom. Hy. kom altyd of die duiwel agter hom is. Hier peul mos toe vir jou 'n buffelbul . . . uit die riet en hy kom soos die donderweer (E. F. Potgieter: Rietbos, 1964, 64). Ek loop skuins sodat die golwe van die kant af kom (P. J. Haasbroek: Skrikbewind, 1976, 101). Noudat hy' $n$ kind het wat kom, hoef hy hom nie meer so in te span nie (I. Jonker in Windroos, 1964, 46). In 'n herhalingsreeks om ' $n$ bepaalde gevoel soos van opwinding, blydskap weer te gee: Kyk hy kom / kyk hy kom / daar is seep aan ie onderkant / kyk hy kom, kom, kom (N. P. v. W. Louw: Nuwe Verse, 1954. 44). In 'n herhalingsreeks met en om veelheid, voortdurendheid aan te dui: Nog kom en kom ruirers koel en moedig met handperde (L. Maré: Nuwejaarsfees, s.j., 76); Daar is baie water. Dit kom en kom (H. A. du Toit, e.a.: Son, s.j., 7).

b. Gerceid, reëlmatig, van tyd tot tyd beweeg [soos bepaal]: Die man kom (elke môre) met hierdie straat langs. Daar kom nog wel mense met hierdie pad. Hier kom baie busse langs. take lati (- Takms)

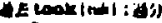

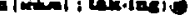

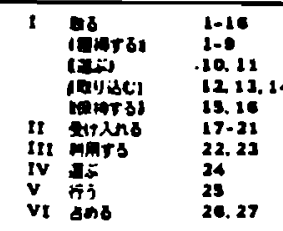

1 (as)

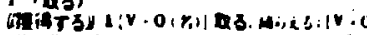

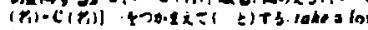

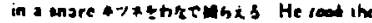

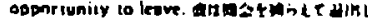

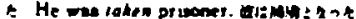
2 li Clich

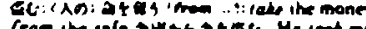

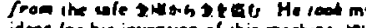
deac lor hie invertion of this mechine. bi

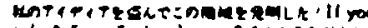

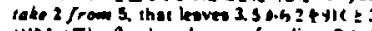

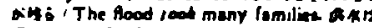
scromone it

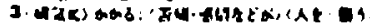

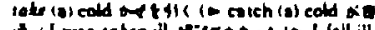

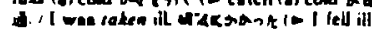

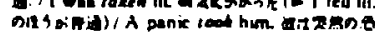
interit.

Learner's Progressive (1990)

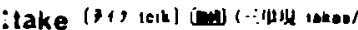

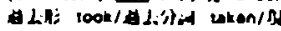
(t.) 分 id taking)

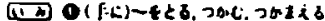

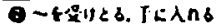

$0-t 6 \rightarrow 2$ i. detis

0 -toitailiculins. $-t a$ a

6. $\left(x^{\prime}\right)+\operatorname{tat}$

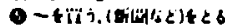

(1)

orivilteb

Disulines

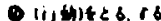

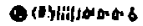

[nit] 0 will you rete the hand of in Wiue child $)$ ho fa] [ f

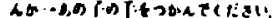

- Jre will take une pal prize in the merainan race A'Lulus

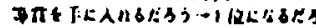
t.

- Don't take onese books to rour

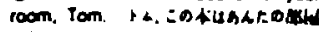

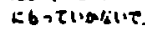

well you tele to boy to has house on

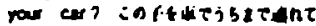

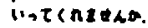

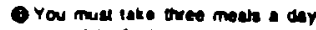

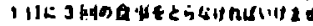
A-OJ IX

Toke the madieine. and rou mo

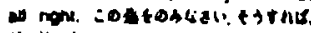
KILIJSL.

First (1986) 
Op makrostrukturele vlak bestaan daar volgens Wiegand (1989a: 375) etlike minder gebruiklike nietipografiese gebruikertoegangsinskrywings wat by die alfabetisering van lemmas in ag geneem moet word. Hy gee as voorbeeld die nie-alfabetiese simbole " $\mathrm{H}_{2} \mathrm{O}$ " en " $\mathrm{H}_{2} \mathrm{SO}_{4}$ ". Die gebruikertoegangsinskrywings bestaan op dié vlak gewoonlik uit 'n streng alfabetiese ordeningstelsel en 'n verskeidenheid tipografiese hulpmiddels. Die bekendste nietipografiese gebruikertoegangsinskrywing op makrostrukturele vlak is waarskynlik die onderskeidende nommers (homoniemnommers) wat dikwels, vanaf deel IX ook in die WAT, in verhewe skrif voor homonieme lemmas gegee word, en die tilde wat in sekere woordeboeke om ruimtebesparingsredes as sogenaamde herhalingsimbool (Hausmann en Wiegand 1989: 344) in die plek van herhalende komponente in opeenvolgende lemmas ingeskuif word.

Toegangsinligting word ook aan die gebruiker verstrek deur die totale aanbod van inskrywings oftewel deur die algehele interne toegangstruktuur van die woordeboek. Dit kom daarop neer dat die opeenvolging van inligtingstipes (in die rekenaarleksikografie soos bepaal deur die rekenaarveldstruktuur) die toeganklikheid van die verskillende aangawes in die woordeboek help bepaal. Is die opeenvolging baie konsekwent, dan sal die woordeboek vir die gereelde gebruiker baie meer toeganklik wees as die woordeboek met 'n wisselende opeenvolging van inligtingstipes, aangesien die gebruiker met verloop van tyd leer waar om sekere aangawes binne die artikel te vind. In die Buro se geval het die vaslegging van so 'n rekenaarveldstruktuur vir inligtingstipes 'n belangrike ordenende rol in die WAT gespeel.

Sien Skema 5 onder Bylaes vir 'n kort uiteensetting van die gebruikertoegangsinskrywing.

\subsection{Rekenaartoegangsinskrywings}

Vervolgens word 'n stelsel van toegangsinskrywings spesifiek vir die rekenaarleksikografie voorgestel wat analoog aan Hausmann en Wiegand (1989: 339 e.v.) se uiteensetting van die toegangstruktuur in die gedrukte woordeboek geformuleer is.

Die toegangsinskrywings wat vir die rekenaar bedoel is, met ander woorde die inskrywings wat deur die rekenaar benodig word om inligting in die elektroniese woordeboekteks te identifiseer met die oog op dataonttrekking, kan die rekenaartoegangsinskrywings of rekenaarontsluitingsinskrywings genoem word (Engels computer access entries / computer access items; Duits Computeraufschlüsselungseinträge). Rekenaartoegangsinskrywings bepaal dus die rekenaartoegangstruktuur (rekenaarontsluitingstruktuur). 'n Hele aantal van hierdie inskrywings, byvoorbeeld die rekenaarveldstruktuur, setkodes en redakteursidentifikasie, sal waarskynlik nooit eers deur die gebruiker gesien word nie, hoogstens miskien ten dele in 'n ruimer elektroniese weergawe van die woordeboek, byvoorbeeld op laserskyf. 
Die toekomstige reikwydte vir die benutting van hierdie inskrywings en van die verskillende soorte merkers kan moeilik bepaal word. Op hierdie terrein sal die leksikografie moontlik nog die grootste en ingrypendste ontwikkelinge ondergaan. ' $n$ Mens hoef bloot aan die huidige aanwending van die hiperteksfasiliteit en die konsep van multimedia met sy dinamiese verbinding van teks, beeld en klank te dink om ' $n$ indruk van die toekomstige benutbaarheid daarvan te kry. Vir hierdie verwagte ontwikkelinge moet die verskillende rekenaartoegangsinskrywings reeds voorsiening probeer maak.

\subsubsection{Rekenaarmerkers}

Die rekenaartoegangsinskrywings kan in twee hoofkategorieë ingedeel word. Die belangrikste is die rekenaarmerkers, byvoorbeeld die formele rekenaarvelde in verskuilde teks waarbinne die inskrywingstipes deur die redaksie aangebied word en waarvolgens die belangrikste dataonttrekkings met die rekenaar gedoen word, die setkodes wat deur die redaksie en die KTP-programmatuur self in die teks aangebring word en wat hoofsaaklik die paragraaf- en karakterformatering van die drukteks bepaal, sekere soorte hakies en tekens, byvoorbeeld $\langle>,\{$ en $\langle »$, wat instruksies aan die rekenaar gee, asook die logiese hiërargiemerkers wat die betekenisonderskeidings ("artikelvlakke") vir die rekenaar aandui maar nooit gedruk word nie.

Daar sou geargumenteer kon word dat die setkodes se primêre funksie dié van vormgewing en sekondêre funksie dié van toegangsverlening is, met ander woorde dat dit nie ware rekenaartoegangsinskrywings is nie. Hier moet egter in gedagte gehou word dat byvoorbeeld digitale karakterformatering as sodanig nie grafies sigbaar is nie; eers op 'n rekenaarskerm of op papier kan dit grafies vergestalt word. Digitaal gesien, is die setkodes dus sinoniem met vetdruk, kursief, boskrif, blanko ruimte en dergelike struktuuraanwysers. Aangesien die rekenaartoegangsinskrywings juis al die struktuuraanwysers insluit, moet die setkode as "digitale struktuuraanwyser" ook daarby ingereken word.

'n Ander soort rekenaarmerker is die sogenaamde sorteerlemma (binne die SORTEERLEMMA-veld). Dit is 'n gestroopte weergawe van die lemma (binne die LEMMA-veld) sodat daar geen aksentteken, sillabeskeidingsteken of struktuuraanwyser soos onderskeidende vetdruk in voorkom nie. Dit het tans slegs een ware doel: die rekenaar gebruik dit vir sy soektogte deur alle artikels met die oog op sortering en dataonttrekking. Wat sy gestroopte voorkoms en funksie betref, kan die sorteerlemma enigsins met die sleutelwoord in die gedrukte woordeboek vergelyk word. In afdeling 6 hier bo is genoem dat die sleutelwoord, 'n gidselement, deel van die eksterne kitstoegangstruktuur uitmaak. Omdat die rekenaar in die reël egter ewe vinnig data aan enigeen van die formele soekvelde in die databasisstruktuur kan onttrek, hou dit geen werklike terminologiese voordeel in om die sorteerlemma nou as 'n soort "interne kitsrekenaartoegangsinskrywing" te beskou nie. 
Meijs (1992: 144) maak ook melding van inskrywings wat net vir die rekenaar bedoel is:

The computer was also used to register additional information not meant for inclusion in the book in its printed form. Thus there are markings to be found for (semantic) subject fields, register, regional origin, etc. on the tape, but not in the book.

Sekere rekenaarmerkers, soos dié deur Meijs hier bo vermeld en die sorteerlemma wat in die WAT se elektroniese teks voorkom, sou later moontlik ook as gedrukte inskrywings in die woordeboek opgeneem kon word, maar dié moontlikheid verander nie hulle ware funksie nie. Hulle is dus nie gereserveerde aangawes nie.

\subsubsection{Redaksionele kommentaar}

Daar is ' $n$ verdere inligtingsdraer wat ook as 'n rekenaartoegangsinskrywing beskou kan word, naamlik die redaksionele kommentaar wat op die artikelinhoud gerig is. In die rekenaarleksikografie maak dit teenswoordig deel van die elektroniese woordeboekteks uit terwyl dit in die handleksikografie tot die ontstaansproses van die woordeboek - die "proses agter die boek" - gereken word. Daar het dit gewoonlik ' $n$ eenmalige funksie by die totstandbrenging van die woordeboek. Daarna kan dit vir alle praktiese doeleindes as verlore beskou word omdat dit waarskynlik slegs nog in 'n woordeboekargief op die manuskrip of drukproewe van die gepubliseerde woordeboek bestaan.

Ook in die Buro van die WAT vorm die redaksionele kommentaar nou grootliks deel van die voltooide elektroniese woordeboekteks. Dit bestaan gewoonlik uit die betrokke Redakteur se voorletters plus die datum waarop die manuskrip van die artikel voltooi is, motivering vir opname en hantering, asook bewysplase en toeligting. Tekens soos " $K$ " en " $\checkmark$ ", wat in die WATmanuskrip aandui dat die inskrywings waarop hulle slaan respektiewelik gekontroleer en verwys is, kan ook hierby ingereken word. Hulle ressorteer nie onder die rekenaarmerkers nie omdat hulle beswaarlik deur die rekenaar in sy soekroetines gebruik sal word. Sodanige aanwending sou hoogstens 'n sekondêre funksie van die tekens kon uitmaak.

Redaksionele kommentaar word by uitstek daardeur gekenmerk dat dit hom primêr tot die redaksie van 'n woordeboek rig. In die Buro van die WAT is dit veral vir die Senior Mederedakteur en in finale instansie vir die Eindredakteur se kennisname bedoe]. Dit verstrek nie alleen belangrike identifiserende en ondersteunende inligting nie maar help ook met die ontsluiting van die inhoudsgerigte aangawes in die woordeboek. Dit word in die vorm van verskuilde teks bewaar sodat dit nie in die gedrukte woordeboek sal verskyn nie. Ofskoon dit ook nuttige inligting vir die gebruiker kan bevat en daarom 
byvoorbeeld in ' $n$ meer volledige elektroniese weergawe van die woordeboek opgeneem sou kon word, is die ware funksie daarvan soos hier bo aangedui. Dit kan ook vir verskillende soorte navorsing, byvoorbeeld oor die betrokke woordeboek self of oor die algemene leksikografie, aangewend word.

Sien Skema 6 onder Bylaes vir 'n kort uiteensetting van die rekenaartoegangsinskrywing.

\section{SAMEVATTING}

Die rekenaarleksikografie word in hierdie artikel beskou as 'n vertakking van die leksikografie. Om by hierdie beskouing aan te sluit, is daar gepoog om die rekenaarleksikografie ook terminologies in die leksikografie in te bed in plaas daarvan om dit in isolasie te benoem. By die beskrywing van dié terminologie is daar gevolglik ook na die algemene leksikografiese terminologie gekyk en waar nodig aanpassings daaraan voorgestel ten einde hierdie vertakking terminologies volledig te akkommodeer.

Daar kan dus oor die invloed van rekenarisering op die leksikografiese terminologie gesê word dat die invoer van enkele nuwe terme en die aanpassing van bestaandes die regstreekse gevolg is van die behoefte aan ' $n$ terminologie wat ook vir die rekenaarleksikografie voorsiening maak. Van hierdie nuwe terminologie is toegangsinskrywing (in die voorgestelde uitgebreide betekenis), en veral rekenaartoegangsinskrywing (waarvan die funksie miskien beter uit sy sinoniem rekenaarontsluitingsinskrywing blyk), waarskynlik die belangrikste voorbeelde.

\section{VERWYSINGS}

\section{A. WOORDEBOEKE EN WOORDELYSTE}

\section{Sleutel tot woordeboeke en woordelyste}

(Die verwysings hier onder is na die lys 2. Bronne)

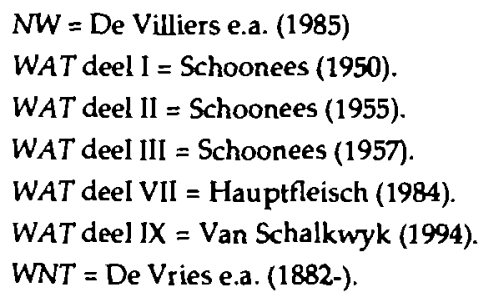




\section{Bronne}

De Villiers, M. e.a. $1985^{6}$. Nasionale Woordeboek. Kaapstad: Nasou.

De Vries, M. e.a. (Reds.). 1882-. Woordenboek der Nederlandsche Tool. Den Haag: M. Nijhoff / 's-Gravenhage: SDU Uitgeverij.

Gove, P.B. (Red.). 1961. Webster's Third New International Dictionary of the English Langruage. Springfield, Massachusetts: Merriam-Webster.

Hauptfleisch, D.C. (Red.). 1984/1991. Woordeboek van die Afrikaanse Taal. Deel VIl/VIll. Pretoria: Staatsdrukker / Stellenbosch: Buro van die WAT.

Schoonees, P.C. (Red.). 1950/1955/1957/1961. Woordeboek van die Afrikaanse Taal. Deel I-IV. Pretoria: Staatsdrukker.

Van Schalkwyk, D.J. (Red.). 1994. Woordeboek van die Afrikaanse Taal. Deel IX. Stellenbosch: Buro van die WAT.

\section{B. ANDER BRONNE}

Gerzymisch-Arbogast, Heidrun. 1989. Standardisierte Wörterbuchartikel des allgemeinen einsprachigen Wörterbuches als Texte: Probleme der Kohärenz und der Thema-Rhema-Struktur. Hausmann, Franz Josef, Oskar Reichmann, Herbert Ernst Wiegand en Ladislav Zgusta (Reds.). 1989. Wörterbücher. Dictionaries. Dictionnaires. Ein internationales Handbuch zur Lexikographie. Eerste deel: 946-956. Berlyn: Walter de Gruyter.

Gouws, R.H. 1989. Leksikografie. Pretoria: Academia.

Hausmann, Franz Josef en Herbert Emst Wiegand. 1989. Component Parts and Structures of General Monolingual Dictionaries: A Survey. Hausmann, Franz Josef, Oskar Reichmann, Herbert Emst Wiegand en Ladislav Zgusta (Reds.). 1989. Wörlerbücher. Dictionaries. Dictionnaires. Ein internationales Handbuch zur Lexikographie. Eerste deel: 328-360. Berlyn: Walter de Gruyter.

Kruyt, J.G. en J.J. van der Voort van der Kleij. 1992. Towards a Computerized Historical Dictionary of Dutch: from Printed Dictionary to Correct Text File. Kiefer, Ferenc, Gábor Kiss en Júlia Pajzs (Reds.). 1992. Papers in Computational Lexicography. COMPLEX '92: 203-210. Budapest: Linguistics Institute, Hungarian Academy of Sciences.

Masereeuw, Pieter C. en Iskandar Serail. 1992. DictEdit: A Computer Program for Dictionary Data Entry and Editing. Tommola, Hannu, Krista Varantola, Tarja Salmi-Tolonen en Jürgen Schopp (Reds.). 1992. EURALEX '92 Proceedings I-II: Papers submitted to the 5th EURALEX International Congress on Lexicography in Tampere, Finland. (Studia Translatologica Series A Volume 2). Deel 1: 257-264. Tampere: University of Tampere.

Meijs, Willem. 1992. Computers and Dictionaries. Butler, Christopher S. (Red.). 1992. Compulers and Written Texts: 141-165. Oxford: Blackwell.

Tono, Y. 1992. The Effect of Menus on EFL Learners' Look-up Processes. Lexikos 2: 230-253.

Van Sterkenburg, P.G.J. 1976. Een woordarchief als basis voor de Nederlandse lexicologie, Van Sterkenburg, P.G.J. (Red.). 1976. De Nederlandse lexicologie tussen handwerk en machine: 83-109. Groningen: H.D. Tjeenk Willink.

Van Sterkenburg, P.G.J. 1984. Van wwordenlijst tol uoordenboek: Inleiding tot de geschiedenis van woordenboeken tan het Nederlands. Leiden: E.J. Brill. 
Weiner, Edmund S.C. 1990. Editing the OED in the Electronic Age. Dictionaries in the Electronic Age: Proceedings of the Fifth Anmual Conference of the UWW Centre for the New Oxford Dictionary: 23-31. Waterloo, Ontario: UW Centre for the New Oxford English Dictionary.

Wiegand, Herbert Emst. 1988. Was eigentlich ist Fachlexikographie? Munske, Horst Haider, Peter von Polenz, Oskar Reichmann en Rainer Hildebrandt (Reds.). 1988. Deutscher Wortschatz: Lexikologische Studien: 729-790. Berlyn: Walter de Gruyter.

Wiegand, Herbert Emst. 1989. Der gegenwärtige Status der Lexikographie und ihr Verhältnis zu anderen Disziplinen. Hausmann, Franz Josef, Oskar Reichmann, Herbert Ernst Wiegand en Ladislav Zgusta (Reds.). 1989. Wörterbücher. Dictionaries. Dictionnaires. Ein intennationales Handbuch zur Lexikographie. Eerste deel: 246-280. Berlyn: Walter de Gruyter.

Wiegand, Herbert Emst. 1989a. Aspekte der Makrostruktur im allgemeinen einsprachigen Wörterbuch: alphabetische Anordnungsformen und ihre Probleme. Hausmann, Franz Josef, Oskar Reichmann, Herbert Ernst Wiegand en Ladislav Zgusta (Reds.). 1989. Wörterbiicher. Dictionaries. Dictionnaires. Ein internationales Handbuch zur Lexikographie. Eerste deel: 371-409. Berlyn: Walter de Gruyter.

Wiegand, Herbert Emst. 1989b. Der Begriff der Mikrostruktur: Geschichte, Probleme, Perspektiven. Hausmann, Franz Josef, Oskar Reichmann, Herbert Ernst Wiegand en Ladislav Zgusta (Reds.). 1989. Wörterbiicher. Dictionaries. Dictionnaires. Ein internationales Handbuch zur Lexikographie. Eerste deel: 409-462. Berlyn: Walter de Gruyter.

Wiegand, Herbert Ernst. 1989c. Formen von Mikrostrukturen im allgemeinen einsprachigen Wörterbuch. Hausmann, Franz Josef, Oskar Reichmann, Herbert Emst Wiegand en Ladislav Zgusta (Reds.). 1989. Wörterbücher. Dictionaries. Dictionnaires. Ein internationales Handbuch zur Lexikographie. Eerste deel: 462-501. Berlyn: Walter de Gruyter.

Wiegand, Herbert Emst. 1989d. Die lexikographische Definition im allgemeinen einsprachigen Wörterbuch. Hausmann, Franz Josef, Oskar Reichmann, Herbert Emst Wiegand en Ladislav Zgusta (Reds.). 1989. Wörterbücher. Dictionaries. Dictiomnaires. Ein internationales Handbuch zur Lexikographie. Eerste deel: 530-588. Berlyn: Walter de Gruyter. 


\section{BYLAES}

\section{SKEMA 1: STRUKTUUR VAN WOORDEBOEKINSKRYWINGS}

Afrikaans: woordeboekinskrywing

Engels: dictionary entry / dictionary item

Duits: Wörterbucheintrag

Voorbeelde:

Enigeen van die funksionele ${ }^{4}$ leksikale items, teksgedeeltes, karakters, simbole, prent- of ander diagramme op enige plek in die woordeboek, m.a.w. in enigeen van onderstaande woordeboekafdelings en met insluiting van die afdelings self.

Onderskeibaar in:

A. Afrikaans: voorwerkinskrywing

Engels: front matter entry / front matter item

Duits: Vorspanneintrag

Voorbeelde:

titel

impressum

inhoudsopgawe

gebruikerstoeligting

lys van redaksionele afkortings

B. Afrikaans: woordelysinskrywing

Engels: word list entry / word list item

Duits Wörterverzeichniseintrag

Voorbeelde:

alfabetiese seksie in die woordelys

indeksletter

sleutelwoord

artikel

artikelinskrywing, o.a. aangawe

4 Met "funksioneel" word hier in aansluiting by Wiegand (1989b: 425) aangedui dat iets ten minste een "ware doel" oftewel 'n primêre funksie het. 
C. Afrikaans: agterwerkinskrywing

Engels: back matter entry / back matter item

Duits: Nachspanneintrag

Voorbeelde:

bronnelys

lys van verbeterings aan of toevoegings tot die woordelys van dieselfde of ' $n$ vorige deel

lys van algemene afkortings

lys van mitologiese of ander name

\section{SKEMA 2: AANGAWE}

Afrikaans: aangawe

Engels: information entry / information item

Duits: Angabe

Kenmerke:

1. Kom slegs in die artikel voor

2. Is inhoudsgerig (verskaf die inligting wat gesoek word) of inhouds- en struktuurgerig (verskaf die inligting wat gesoek word en die inligting wat daarnatoe lei)

Tipes:

1. Leksikale aangawe, bv. lemma, definisie, sinoniem, gebruiksvoorbeeld

2. Nieleksikale aangawe, bv. betekenisnommer, aksentteken, wiskundige simbool, formule (soos $\mathrm{H}_{2} \mathrm{O}$ vir "water"), simboliese voorstelling van 'n spesialiteitsgebied (soos 'n vliegtuigie vir "lugvaart")

3. Verdere onderskeidings is moontlik, bv. tussen linguisties en ensiklopedies, implisiet en eksplisiet, gestandaardiseerd en ongestandaardiseerd (Wiegand 1989b: 430 e.v.)

Funksie:

Teksverdigting en besparing van drukruimte (veral waar aangawes gestandaardiseerd is) 


\section{SKEMA 3: STRUKTUURAANWYSER}

Afrikaans: struktuuraanwyser / struktuurmerker Engels: structural marker / structural indicator Duits: Strukturanzeiger

Kenmerke:

1. Kom hoofsaaklik binne die artikel en in enkele gevalle op ander plekke in die woordelys voor

2. Is struktuurgerig ten opsigte van artikelinskrywings

Tipes:

1. Tipografiese struktuuraanwyser (grafiese middel wat 'n teksgedeelte laat kontrasteer), bv. kursief, onderstreep, vet, hoofletter, superskrif, ongemarkeerd, blanko ruimte

2. Nietipografiese struktuuraanwyser (fisiese karakter wat 'n aangawe of sy komponente skei, bind of merk), bv.

- intern: skeidingsteken (nie interpunksieteken nie), soos komma, kommapunt, dubbelpunt, aandagstreep; bindingsteken, soos 'n stel hakies; merkteken, soos a en - voor bepaalde soorte aangawes

- ekstern: indeksletter, soos A, B, C, voor die ooreenstemmende alfabetiese seksie van die woordelys

Funksies:

1. Bepaling van die toegangstruktuur

2. Onderskeiding van sowel aangawes as inskrywings binne in aangawe (deelaangawes) 


\section{SKEMA 4: TOEGANGSINSKRYWING}

Afrikaans: toegangsinskrywing / ontsluitingsinskrywing

Engels: access entry/access item

Duits: Aufschlüsselungseintrag

Kenmerke:

1. Kom hoofsaaklik binne die artikel en in enkele gevalle op ander plekke in die woordeboek voor

2. Is struktuurgerig ten opsigte van artikelinskrywings

Tipes:

1. Enigeen van die deels struktuurgerigte aangawes

2. Enigeen van die struktuuraanwysers

3. Enige ander inskrywing in die woordeboek wat toegang tot inligting in die artikel verbeter

Funksie:

Bepaling van die toegangstruktuur met hulpmiddele binne en buite die artikelstruktuur

\section{Kommentaar:}

Die nut van hierdie term is daarin geleë dat dit alle inligtingontsluitende woordeboekinskrywings, ook dié wat nie goed onder enigeen van die ander genoemde inskrywingskategorieë teregkom nie, saam benoem en sodoende vir die terrein van die uitsluitlik rekenaarleksikografiese terminologie voorsiening maak op ' $n$ wyse wat hierdie terminologie by die bestaande (hand)leksikografiese terminologie laat aansluit 


\section{SKEMA 5: GEBRUIKERTOEGANGSINSKRYWING}

Afrikaans: gebruikertoegangsinskrywing / gebruikerontsluitingsinskrywing Engels: user access entry / user access item Duits: Zugriffseintrag / Zugriffssegment / Benutzeraufschlüsselungseintrag

Kenmerke:

1. Kom hoofsaaklik binne die artikel en in enkele gevalle op ander plekke in die gedrukte woordeboek ${ }^{5}$ voor

2. Is struktuurgerig ten opsigte van artikelinskrywings in die gedrukte woordeboek

Tipes:

1. Enigeen van die deels struktuu rgerigte aangawes, bv.

- leksikaal: soekwoord in gemerkte leksikale items (die inleidende "lede" in die gelemmatiseerde uitdrukking "lede: met lede oë"); deelaangawe "sin." wat die formele sinoniem in die aangawe voorafgaan en merk ("sin. ledevoorstel"); aanloop voor sekere voorbeelde ("Ook fig."); opskrif "UITDR. IDIOMATIES" bo die artikelrubriek vir idiomatiese uitdrukkings

- nieleksikaal: hiërargiemerker (soos 'n betekenisnommer); simboliese voorstelling van 'n spesialiteitsgebied (soos 'n vliegtuigie vir "lugvaart"); grafiese illustrasie

2. Enigeen van die struktuuraanwysers, bv.

- tipografies: kursief, onderstreep, vet, superskrif, blanko ruimte

- nietipografies: skeidingsteken, soos kommapunt, dubbelpunt, aandagstreep; hakies; merkteken (soos $\approx$ en - voor bepaalde soorte aangawes)

3. Enige eksterne inskrywing wat gebruikerstoegang tot inligting in die artikel verbeter, bv. sleutelwoord en gepaardgaande interne vindplekaanduiding (soos "1LIG I, uitdr.") boaan elke bladsy; indeksletter (soos A, B, C) voor elke alfabetiese seksie van die woordelys

Funksie:

1. Bepaling van die toegangstruktuur van die gedrukte woordeboek

2. Voorkoming van te hoë teksdigtheid

Die feit dat 'n gebruikertoegangsinskrywing primêr ' $n$ inskrywing vir die gebruiker van die gedrukte woordeboek is, beteken nie dat dit nie ook in die teks van die elektroniese woordeboek kan voorkom en selfs deur die rekenaar in sy datasoektogte gebruik kan word nie. Dit verander in so 'n geval egter nie sy status tot dié van 'n rekenaartoegangsinskrywing nie; dit bly primêr 'n gebruikertoegangsinskrywing. Die vervolgens aangeduide tipes en funksies het dus, ook waar dit nie uitdruklik vermeld word nie, primêr betrekking op toegangsinskrywings in die gedrukte woordeboek. 


\section{SKEMA 6: REKENAARTOEGANGSINSKRYWING}

Afrikaans: rekenaartoegangsinskrywing rekenaarontsluitingsinskrywing Engels: computer access entry / computer access item Duits: Computeraufschlüsselungseintrag

\section{Kenmerke:}

1. Kom hoofsaaklik binne die artikel en in enkele gevalle op ander plekke in die elektroniese woordeboek ${ }^{6}$ voor

2. Is struktuurgerig ten opsigte van artikelinskrywings in die elektroniese woordeboek

Tipes:

1. Rekenaarmerker (enige funksionele inskrywing van die redaksie of die rekenaar self, wat deur die rekenaar gebruik word om ander inskrywings vir die woordeboekgebruiker te identifiseer en die inligting daarin te ontsluit), bv.

- rekenaarveldmerker: enigeen van die begin- of eindmerkers wat die rekenaarvelde aandui waarbinne die redaksie inligting in die vorm van inskrywings aanbied, soos $<$ LEMMA $/>\ldots<$ LEMMA $\mid>$; $<$ DEFINISIE $/>\ldots$ $\langle$ DEFINISIE $\backslash>$

- programmeerkode: kode wat instruksies aan die rekenaar gee, soos sekere soorte hakies en tekens, o.a. <>, \{\} en «»

- logiese hiërargiemerker: merker wat die betrokke betekenisonderskeiding ("artikelvlak") vir die rekenaar aandui

- setkode: kode wat deur die redaksie of die program self in die teks aangebring word en wat as digitale struktuuraanwyser hoofsaaklik die karakter- en paragraafformatering van die drukteks bepaal

- enige ander redaksionele inskrywing wat deur die rekenaar vir die ontsluiting van inligting gebruik word, soos die sorteerlemma (weergawe van die lemma sonder enige formatering of aksentteken binne die SORTEERLEMMA-veld), waarvolgens die rekenaar artikels bv. alfabeties orden

Met die term "elektroniese woordeboek" word hier nie net die kommersiële rekenaartoeganklike woordeboek, bv. op CD-ROM, bedoel nie, maar ook die elektroniese woordeboekteks wat vir veeldoelige dataonttrekking gestruktureer is en bv., soos in die WAT se geval, gebruik word vir die totstandbrenging van die gedrukte woordeboek, die rekenaartoeganklike woordeboek en verskillende afgeleide produkte. 
2. Redaksionele kommentaar (enige inskrywing deur die verantwoordelike redakteur, wat toeligtende, identifiserende, motiverende of ander ontstaansinligting oor ander artikelinskrywings bevat, primêr vir redaksionele kennisname bedoel is en as integrale deel van die elektroniese woordeboekteks bewaar word), bv. die redakteur se naam, die datum waarop die manuskrip voltooi is, motivering vir opname en hantering, bewysplase, aanvullende materiaal en tekens soos " $K$ " en " $\checkmark$ ", wat aandui dat die inskrywings waarop hulle slaan, respektiewelik gekontroleer en verwys is

Funksies:

1. Bepaling van die toegangstruktuur

2. Volledige demarkering van inligting deur sowel die begin as die einde van veldgewys gestruktureerde inskrywingstipes aan te dui

3. Fisiese onttrekking, lysting en aflaai van inligting in elektroniese vorm

4. Verskaffing van toegang tot ontstaans- en ander inligting oor die woordeboek wat primêr aan die redaksie geadresseer is 